\title{
THE STORY OF THE BACTERIA
}

\section{PRUDDEN}




\section{líbrary}

BRIGHAM YOUNG UNIVERSITY

FROM

CALL NO. ACC. NO. 
Date Due

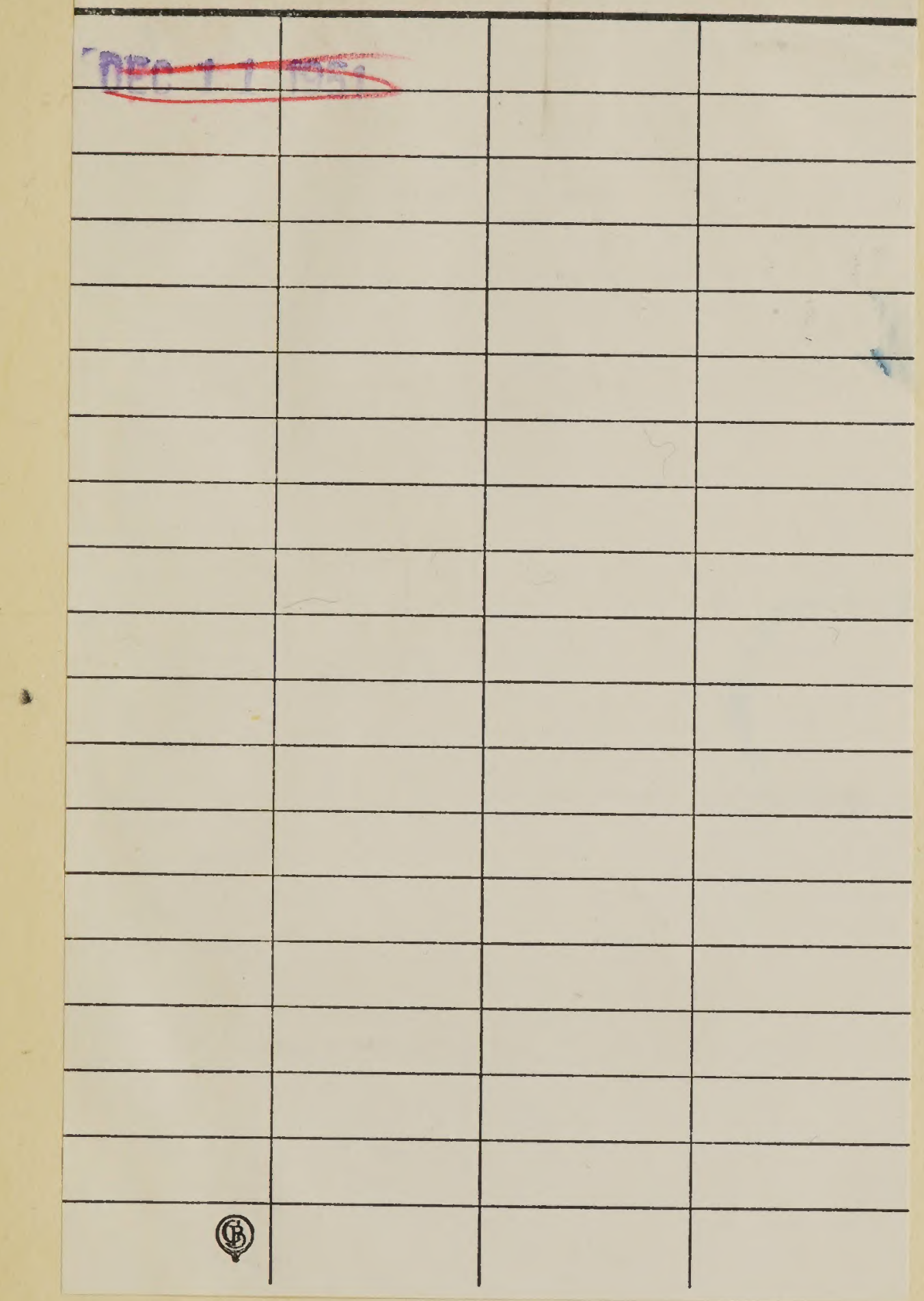



Digitized by the Internet Archive in 2020 with funding from Brigham Young University

https://archive.org/details/storyofbacteriat00prud 

. 


\title{
WORKS BY T. MITCHELL PRUDDEN., M.D.
}

DIRECTOR OF THE PHYSIOLOGICAL AND PATHOLOGICAL LABORATORY OF THE ALUMNI ASSOCIATION OF THE COLLEGE OF PHYSICIANS AND SURGEONS, NEW YORK

\begin{abstract}
A Manual of Practical Normal Histology. I6mo, cloth . . . . . . . . . \$1 25

"A handy book for students. Very practical and very intelligible." The American Specialist.

"We are happy to find that a really valuable addition has been made to literature. . . The author is evidently a master of his craft, and fully understands the practical details. We are surprised at the amount of information put in such small compass." -Boston Medical and Surgical Fournal.
\end{abstract}

The Story of the Bacteria. I6mo, cloth . 75 cents

"It is written in clear, concise sentences, without any effort at display, and can be read with profit and enjoyed by any intelligent reader as well as by the most scientific physician."-Chicago Interocean.

Dust and Its Dangers. Uniform with "The Story of the Bacteria." Illustrated . . . . 75 cents

"It is in one sense an alarmist book, but it alarms in a proper direction, and performs a service that cannot be overvalued. . . . The book is to be warmly commended, and should attract general attention." -Boston Gazette.

Drinking-Water and Ice Supplies, and Their Relaw tions to Health and Disease. I6mo, cloth, illustrated, 75 cents.

"Dr. Prudden's little book is crammed with information-practical information-which to thousands of families would be worth, if duly read and heeded, far more than money "-Hartford Times.

\section{G. P. PUTNAM'S SONS, Publishers, NEW YORK AND LONDON,}





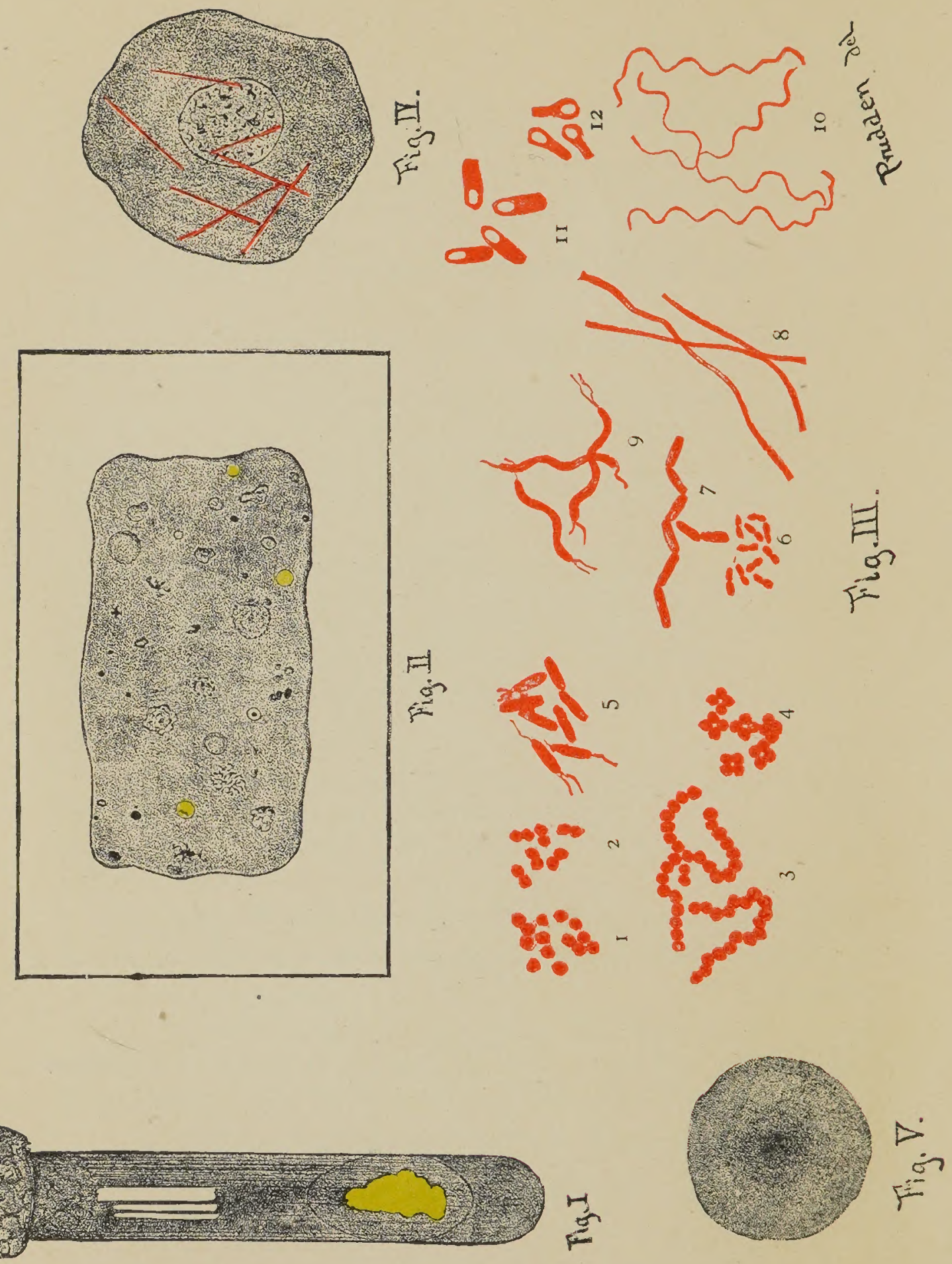




\section{EXPLANATION OF THE PLATE.}

FIG. I.-A large mass of baeteria growing in a tube on a transparent eulture medium. This speeies is ealled Mierococeus luteus, (page 40) and is a "pure eulture" (page 35).

FIG. II.-A gelatin plate culture (pages 36,37 , and 38), showing several colonies of different species of bacteria growing in the thin layer of solidified gelatin. Eaeh eolony is eomposed of thousands of individual baeteria. (See Fig. v.)

The yellow colonies are those from whieh a small portion was taken on the end of a sterilized needle and planted in the tube shown after a few days growth in Fig. I.

The tube and plate in Figs I. and II. are represented of about one third the natural size.

Fig. III.--Several different forms of bacteria represented as they look when stained with one of the anilin dyes and magnified about I, ooo times (see pages I5, 39, and 40).

Nos. I and 2: Microeoeei, single and in pairs. No. 3: Mieroeneci in chains, ealled streptococei. No. 4: Tetrads of mieroeoeci. Nos. 5, 6, 7, and 8 : baeilli, showing different sizes and groupingsin No. 5, cilia are seen at the ends of some of the baeilli (page I6). Nos. 9 and Io: spiral baeteria; those in No. 9 with cilia. Nos. I I and I2: baeilli with spores (page I9).

FIG. IV.-A cell in which are seen seven long slender bacillimagnified about 3 , ooo times.

FIG. V.-A single eolony as seen under a low power of the mieroseope on the plate culture, Fig. II. This is magnified about 20 times. 



\section{STORY OF THE BACTERIA}

AND THEIR

\section{RELATIONS TO HEALTH AND DISEASE}

T. MITCHELL PRUDDEN, M.D.

128921

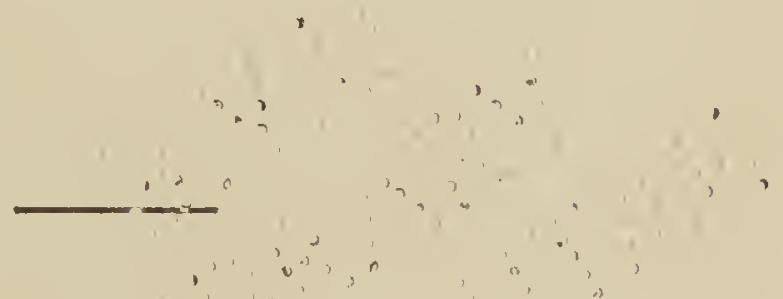

NEW YORK \& LONDON

G. P. PUT N A ' S SON S

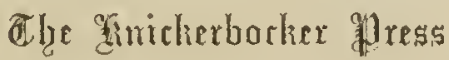


COPYRIGHT BY

T. MITCHELL PRUDDEN

I 889

Jbe Ninickerbocker Press 


\section{PREFACE.}

THe Bacteria are so often nowadays the subject of discussion and discourse; so much which is at once disquieting and untrue is said about them, and they are withal of such practical importance to the health and well-being of everybody, that it has seemed to the writer worth while to bring together in some simple fashion a little of our knowledge about them.

The aim then of this book is to present some facts from a small corner of the domain of Science in such form as will be plain to the unscientific, and with these some extracts from the lore of the physician which will, it is hoped, be both interesting and useful to the lay reader.

\section{T. M. P.}





\section{CONTENTS}

CHAPTER

PAGE

I. The Cells Which Compose the Human Body-

What 'THEY ARE, AND WHAT THEY DO • . . I

II.-What the BaCteria ARE, ANd Some of the Things

WhICH TheY DO . . . . . . . It

III.-HOW 'THE BACTERIA ARE STUDIED • 。 • . 25

IV.-SOME BACTERlal CURiosities . • • . . 4 I

V.-The Bacteria As Man's Invisible Foes 。 • . 52

VI.-The Bacteria of Surgical Diseases • • • . 59

Vit.--Tile Bacteria Whichi Cause Consumption, or

Tuberculosis . . . . . . . . 70

VIIL.-BACTERIA AND TYPHOHD FeVer . . . . . . $S_{4}$

IX.-Tine Relations of Bacteria to Asiatic Cholera • 90

X.-The Relation of Bacteria to Dirhtileria, PnetMONIA, SCARlet-FEVER, ETC. • • • . . 96

XI.-IMpure FoOd AND AIR as Sources of Bacterial.

INFECTION • . . . . . . . IO3

XII.-IMPURE WATER AND ICE AS A SOURCE OF BAC'TERIAL

DISEASE • . . . . . . . II6

XIII.-TIE END OF THE STORY OF TIL BACTERIA • . I34

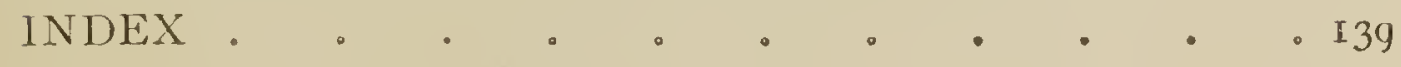




\section{THE STORY OF THE BACTERIA.}

\section{CHAPTER I.}

THE CELLS WHICH COMPOSE THE HUMAN BODY -WHAT THEY ARE, AND WHAT THEY DO.

REFORE beginning to study those low1 liest and smallest forms of life, the bacteria, I wish to ask my reader to look with me in this chapter at some of the higher and more complex forms of living things. In doing this we shall be following the course which scientific research has taken, and from the vantage-ground which we shall gain we shall be able the more easily to spell out the simple but significant story of the bacteria, which it is the purpose of this little book to tell.

In general anatomy we learn that the body consists of a bony framework, around which 
various tissues and organs are securely and compactly grouped. When we have learned the size, shape, number, relations, and names of all these parts, our study of macroscopic or general anatomy is done. If, however, entering that department of anatomy known as histology, or minute anatomy, we trace the manner in which these parts are made beyond the point where the naked eye can avail us, we find that they are all composed of certain tiny organisms called cells, and that these cells are held together and associated by certain materials which lie between them.

Just as the chemist has his atoms and molecules, to which in the last analysis he refers the properties which all known substances possess, and explains by differences in their nature and movements the various chemical phenomena which matter exhibits, so we may refer both the structural features and all the activities of the animal body back to the structure and activities of our elements-the cells. While the chemist, however, must infer the existence of his atoms from their deeds, armed with the microscope we can see our 
cells, observe the things they do, and definitely trace out their life-history.

Cells are little masses of matter of peculiar chemical constitution, and of varied shape and consistence, which at some time exhibit that complex of phenomena which we call life: and the life of one of the higher animals is simply the sum of the more or less independent but co-ordinated lives of the cells which compose it, all acting in harmony.

Living things differ from the non-living in that they have certain activities through which their life is expressed. In the first place, they are capable, in spite of various opposing forces, of maintaining their individuality, and by holding a balance between waste on the one hand and assimilation on the other, a series of capacities arise which we call nutrition, growth, and development. Living things, in the second place, possess certain activities by means of which they are capable of producing new individuals like themselves-in other words, they are endowed with the power of reproduction. Lastly, living bodies, in response to varied influences, are capable of doing certain 
things in the way of movements or of elaboration of peculiar chemical products, etc., and these are called their functions.

It will be observed that in enumerating these activities I have spoken of them not as characteristic of man, or of any special animal or plant, but of living things in general. All life finds expression in these ways. The means by which the living being does these things may be in one case exceedingly primitive, and in another very complicated, but this does not alter the essential character of the ends which it achieves.

If you tie a bit of muslin over a water faucet and allow the water to trickle slowly through it for a few hours, you will find on removing it that a more or less abundant greenish scum has collected on the cloth. Wash this carefully into an open dish, and let it remain for a few days in a light warm place, and then examine the sediment under a microscope, and you will find a very celebrated creature. It is called an amœba. It looks like a little lump of transparent or slightly granular jelly. You will see it thrusting out portions of itself 
in the form of longer or shorter arms, and then withdrawing them and sending out others in another place, apparently in the most aimless way; or you may sce it rolling itself over and over, or, if I may so say, flowing along so that it travels with considerable speed. Perhaps some microscopic vegetable may lie in its way, and it will flow over and enclose this, and, after digesting portions of it, expel the residue from whichever side or sur. face of its body may be most convenient. If, in a quiescent condition, it be touched by an external object, you may see it move in direct response to the irritation. If you are fortunate in your observation, you may see a constriction appear around some part of the lump, which grows gradually deeper until a portion of the mass separates from the rest and crawls off on its own hook as a new and independent amœba. It has no lungs and yet it breathes; no mouth, still eats; no definite shape, yet grows; no nerves, yet is sensitive; no sex, yet may give birth to endless progeny.

Now this amoba is one of the lowest and simplest of creatures, and is the type of a 
cell - a creature which is composed of a single cell-and all the activities which I have mentioned as characteristic of living things are exhibited in it. It is a perfectly independent being, doing every thing for itself, and doing nothing particularly well, except, perhaps, performing the function of reproduction, which it does with such ease and nonchalance as leaves little to be desired. The young which it produces are just like the parent, single cells, and their very first post-natal act may be to give birth to other amœbas.

Now let us advance a step in the scale of being, to an animal composed of several cells. There is a little creature, one of the group of sponges, called olynthus. Let us start with the ovum of the animal, which is a single cell, not very unlike the amoba in appearance. Under suitable conditions, this cell divides as the amoba does, and two cells are produced, just exactly alike. They do not separate, however, as do the amœbas, to become independent individuals, but remain fastened together; then each cell divides again, and these still further, until we have a little mass 
of cells all looking alike, and the whole somewhat resembling a mulberry in shape. But now a change comes; the cells on the outside become longer than the rest, and little hairlike processes, called cilia, grow out from them and begin to vibrate to and fro, and, acting like tiny oars, propel the little creature through the sea. Presently the rest of the cells arrange themselves so as to form a central cavicy, with an opening at one side, the whole looking like a tiny cup. The animal now attaches itself to a sea-weed or a rock, and no longer needing the locomotive cilia, they disappear; but as it can no longer travel, it can no longer seek its food, which must be brought to it. Accordingly, we presently find that through the sides of its body little holes appear, and the cells lining the central cavity lengthen and develop cilia, whose vibrations maintain a current of water through the body, which brings with it oxygen and food. This is the adult olynthus.

Now observe, if you please, what has happened in the development of this little creature. A single cell divided into several cells, at first all just alike, and all doing the same thing. 
But soon, as if in response to the growing needs of the animal, certain of the cells developed a special apparatus, and a special capacity for performing rapid movements, and this capacity was associated with changes in the form of the cells, - a specialization which signalized its advance to a higher type of existence.

Just here we come upon the great principle, in a very simple form, upon which the enormous differences between higher and lower animals rest,--the principle of the physiological division of labor in cells. The more perfect the individual is, the more elaborate do we find the expression of this principle.

The difference between the amoba and the olynthus from our present point of view - that which makes of the latter a higher animal than the former-is that it has a certain group of cells set apart to do a special thing, to move rapidly; Amoba moves, but not so rapidly nor with such directness. If another group of cells were set apart in olynthus to do the digesting, no new cell powers would be developed which the amoba does not possess, the primitive assimilating power would simply be 
specialized and intensified, and the animal would have risen to a higher grade of being.

It would not be difficult, did time permit, to trace the manner in which, as we pass upward in the animal series, certain groups of cells become more and more elaborate in structure as they assume higher and more specialized capacities. We cannot tarry for this, but will glance for a moment at the exhibition of this principle in the development of man. In man, too, life commences in a single cell called the ovum; a cell which, though harboring potentialities of the highest order, in many respects greatly resembles our little denizens of the water. This cell, under suitable conditions, divides and subdivides, forming a little cluster of cells all looking alike. Then these cells arrange themselves in layers; some of them assume special forms as they increase in number, and develop special capacities, and group themselves to form the various tissues and organs of the mature body, which finally is formed of a grand community of co-ordinated groups of cells, some of which have acquired the power to do special things in the most 
perfect way, while others have remained in a condition of comparatively low organization.

Let us look at two examples of these two types of cells from the adult body-first at certain muscle cells. These in the very young animal look just like many other cells; they are individuals, they are alive and their life finds expression, just as the amoba's does, in certain activities - nutrition, growth, function, and reproduction. Presently they become longer than their neighbors, little striations appear along their sides, they grow long and narrow until at last they are little thread-like bodies wish a very complicated internal structure, anu are grouped in bundles to form the muscles as we see them with the naked eye. The peculiarities of structure of these muscle fibres are necessary for the performance of the work which they have specially to do-namely, the accomplishment of rapid and powerful movements. Now the capacity of the muscle cells for doing this work has been acquired, if I may say so, at the expense of some of the other capacities which they originally possessed in common with other cells. Thus the power 
of reproduction is in them almost if not quite completely absent. They can also no longer seek out and take up crude food, but it has to be prepared for and brought to them, and in order that this may be done certain other cells in the body develop the power of elaborating a peculiar fluid-gastric juice, which helps to change the crude food so that it finally becomes fitted for the nourishment, among others, of the special workers, the muscle cells; other cells - the red blood cells-develop the capacity of bringing them oxygen, and in doing so have lost many capacities which are possessed by lower forms. Other cells develop in a peculiar way to form the nerves by which all the various parts of the body are brought into harmonious action, and so on. Thus we see in the higher animals each highly developed cell working for the others as well as for itself and for the organism as a whole, only its chief endeavor is concentrated in some one special thing, and as a result of this concentration some of the more general cell powers are lost or diminished.

Did time permit, I should like to picture for 
you the character and destiny of some of the lower forms of cells, which we find in the human body,- those which have not undergone that differentiation in structure and function which belongs to higher types; to speak of the marvellous potentialities which are dormant in them; to show you how their very simplicity of existence, the absence of special powers, and their boundless capacity for reproduction particularly fit them to become the conservators of the individual; to indicate what an important role some of them play in the healing of wounds and in the formation of new tissues. So we are not to think of the lower forms of cells in the body as insignificant, because under ordinary circumstances their being and performances are humble and inconspicuous, for they seem to be ever ready, either resting quietly in their tiny nooks within the solid tissues, or driven restlessly in the rushing torrent of the blood, to assume again the lowly but active powers of embryonic cells, and begin when necessary the work of reproduction and repair.

These cells have, too, a most important role; 
as we shall see by and by, in combating the incursion of certain forms of bacteria which now and then obtrude themselves into this happy family of cells which makes up the human body.

We have thus seen that all the varied structures and functions of the human body are but the combined expression of the structure and lives of the cells which compose it, all co-ordinated and working in harmony by means of self-built, cellular mechanism; that, starting with the type of the most simple of living things, a single cell, the finished organism is an aggregate of the progeny of the original cell, some groups of which have developed special forms and powers, in accordance with a universal principle in nature; that the doctrine of evolution, even should the record of the rocks be incomplete and perfect continuity in the grouping of living species fail, still finds epitomized in every animal and plant which has escaped from the primitive simplicity of the lowest forms, a most pertinent illustration and convincing proof. 


\section{CHAPTER II.}

WHAT THE BACTERIA ARE, AND SOME OF THE THINGS WHICH THEY DO.

THERE are many very good reasons for believing that when life first appeared upon the earth it showed itself in a very simple and primitive form, in some such form perhaps as we have seen in the amoba or other simple cells. But as the ages passed, in accordance with the principles of the physiological division of labor, which we have glanced at in the last chapter, many of the living beings gradually assumed more and more complex forms and capacities.

Not all living things, however, shared in these evolutionary changes. There is, in fact, a great group of lowly plants, so small as to be quite invisible to the naked eye, and which until within a few years have been entirely unknown to man,. which still linger in the 
primitive simplicity which we imagine to have belonged to the earth's earliest denizens. These are the bacteria.

So small are the bacteria, and so simple in their structure and activities, that it has not been an easy task for scientific men to decide whether they belonged among animals or plants. It is now definitely settled, however, that they are plants, and are closely related to the algx.

The bacteria vary a good deal in shape, but in general they are either spheroidal or ovoidal, like a billiard-ball or an egg; or rod-shaped, like a lead-pencil ; or spiral-shaped, like a corkscrew.

They are in general so very small that we can hardly form a conception of them except by comparison with some well known objects. One of the most common of the bacteria is a little rod, so small that if you were to put fifteen hundred of them end to end, the line would scarcely reach across the head of an ordinary pin. If you look at them with a magnifying power so great that, if it could be applied to him, it would make a man look 
about four times as big as Mount Washington, they do not look larger than this. We can make out, however that they are made up of a slightly granular material surrounded by a somewhat denser envelope.

The bacteria appear under the microscope as pale translucent bodies, and the student usually finds it necessary, in order to see their outlines distinctly, to stain them with some one of the aniline dyes-red, or blue, or violet, -when they become very distinct.

When they are alive and suspended in fluids many of the rod-like and spiral bacteria can perform the most elaborate and astonishing series of movements. They swim slowly, they turn about, they roll over, they wriggle, dart forward, retreat, bang against one another, rest awhile, sway to and fro, plunge off again, and so on through varying phases of movement until the head swims and the eye tires in following them. This movement, in some of the bacteria at least, is induced by a little hairlike projection from the end of the organism, which vibrates rapidly to and fro. It is very difficult to see these little projections or cilia, 
even with the most powerful microscopes, but notwithstanding this, they have actually been photographed, and in some cases the image of the cilia, which failed to make an impression on the retina, has been caught and made permanent by the sensitive plate in the camera.

Warmth, moisture, oxygen, and a certain amount of organic matter are the simple conditions which are required for their activities.

When the conditions are favorable they may increase in number to a degree which is limited only by their surroundings. A little constriction appears around one of the bacteria; it grows a little longer, a partition forms across the middle, and in the place of one there are two full-fledged bacteria. These may at once fall apart and each new individual go on dividing as before, or they may cling together, forming threads or chains of varying length, or clumps or masses.

So rapid is this process of reproduction that a single germ by this process of growth and subdivision may give rise to more than sixteen and a half millions of similar organisms within twenty-four hours. It has been calculated by 
an eminent biologist that, if the proper conditions could be maintained, a little rod-like bacterium, which would measure only about a thousandth of an inch in length, multiplying in this way, would in less than five days make a mass which would completely fill as much space as is occupied by all the oceans on the earth's surface, supposing them to have an average depth of one mile.

Let not the timid soul tremble, however, for the principles of the survival of the fittest and the influences of environment have kept our prolific organisms so well in check that the world had grown very old and its favored nursling, man, pretty well along in experience and skill before ever he recognized the existence of these his microscopic contemporaries and possible ancestors.

The struggle for existence goes on where varying forms of bacteria are growing as fiercely as ever it did among more highly organized beings. One race succeeds another, one species adapts itself to the conditions which brought about the extinction of its predecessors. Hardy individuals struggle with their 
weaker neighbors as the food grows scanty in their microscopic seas, and the weaker goes to the wall.

Many forms possess the power of living and multiplying in the manner described above so long as the proper conditions prevail, but when life, owing to some change in the environment becomes no longer possible, the vital powers collect themselves in a little shining mass in one end of the bacterium, which surrounds itself by a dense membrane, and in this form, which is called a spore, the individual can survive adverse conditions which in the ordinary form would have destroyed its life. Restore it to the needed conditions and the spore swells into a bacterium again, and the roots of a new ancestral tree begin to sprout.

These bacteria are really very simple forms of cells, and like the cells which we have looked at in the last chapter, their life expresses itself in certain activities; they move, they nourish themselves and grow, they reproduce their kind. They have the power in carrying on the processes of their own nutrition, when moisture and air are present, of tearing to 
pieces, in the chemical sense, dead organic material, using up such parts of it as they need for their own purposes, and setting free the rest in such form as to be available for the use of other living things.

Everybody knows who thinks about it, that the supply of such material as makes up the bulk of the tissues of man, animals, and plants, on this earth, is limited. So that if things were not so arranged that living beings should have the use of the material which goes to make up their bodies for only a comparatively short time, the supply would run short and new beings could not continue to appear.

When that mysterious group of activities which we call life ceases to be manifested, in animals and plants alike, if moisture and oxygen and sufficient warmth are present, that process which we know as putrefaction or decay begins, by which the old combinations of matter are broken up and the material set free for the use of other beings. Now just here enter the bactcria. It is they who tear these old organic compounds asunder, use a little of them as may suit their own needs, and turn 
over the rest to their earth neighbors, who have got higher up the scale of being, but not yet so far as not to need absolutely and hourly oxygen, hydrogen, nitrogen, and carbon, to keep their life's furnaces a-going.

Milk is a most excellent food for many forms of bacteria, and among those which are commonly present in milk is one which causes it to become sour when left to itself. Other forms of bacteria develop those peculiar chemical compounds which give to cheese its special and varying flavors. It is, in fact, a very motley group of chemical substances which these bacteria set free in feeding themselves on nature's waste organic materials. Sometimes they are very bad smelling gases, sometimes aromatic substances, sometimes they are sweet, sometimes they are sour. But sooner or later they are used by some animal or plant, and so again enter the domain of life. Thus ever in ceaseless alternations between life and death these elemental combinations come and go. And ever since life emerged from its primal simple forms on the earth, the bacteria have silently gone on tearing the worn-out and useless to 
pieces and turning it over in new combination to other forms of life.

It was formerly believed that such lowly organisms as the bacteria could spring at once into being wherever in nature the conditions were favorable, but this notion of spontaneous generation has long since been given up, because it was shown to have depended upon insufficient and crude observation. We now believe that every living thing comes from some pre-existing living thing, be it man, beast, plant, or cell, and this principle holds true as well among the bacteria as among more highly organized beings.

There is an enormous number of different species of bacteria, each one of which appears to preserve its individual characters under all the varying conditions and vicissitudes to which it is subject. They are to be found everywhere in nature. Where putrefaction and decay are going on they are most abundant, but where any form of life can exist they are present, either dry and inactive, or where moisture and food are present, growing and multiplying in such degree as their surroundings will per- 
mit. In all natural surface waters, in the soil, on all fruits, vegetables, and plants, in the mouths and digestive canals of men and animals, on the skin, wherever dust can go or collect, there are bacteria of various forms in greater or smaller numbers.

So common and abundant are the bacteria that we are constantly taking enormous numbers of them into the system with all of our uncooked food. We should not, however, think of these little organisms which we thus unwittingly consume as things necessarily unclean or unwholesome, for they are only little cells after all, and nearly all the food which we consume, whether animal or vegetable, is made up of masses of cells which are either fit to eat in their natural condition, as in the pulp of fruits, or become so by simple cooking or other manipulation.

There is really very little difference so far as wholesomeness is concerned between, the few thousand vegetable cells which we call bacteria which may be clinging to the surface of a grape, and a few hundred vegetable cells of larger size of which the grape itself is com- 
posed. Both are alike worked over by the digestive organs, under ordinary conditions, into nutritive material for the uses of the body.

There are poisonous vegetables, and there are, more 's the pity, as we shall see by and by, poisonous bacteria, but we do not shudder as we swallow a mushroom to think what might have happened to us if we had swallowed a poisonous toadstool instead; we simply trust to the gardener, or if he is dishonest or ignorant, see to it ourselves that the poisonous are not liable to get in with the other plants, and then go on enjoying our delicacies like sensible people.

It will thus be seen that the rôle of the bacteria in nature, though humble and silent, is an exceedingly important one. They are indispensable to the continuance of the higher forms of life upon the earth. They may well be called man's invisible friends. 


\section{CHAPTER III.}

HOW THE BACTERIA ARE STUDIED.

T F you take a small whisp of hay, put it in 1 an open jar, and covering it with water, set it in a warm place for a day or two, you will presently see that the water which was at first perfectly clear, begins to get turbid, and, after a while, a grayish scum collects on the top. Now the water begins to give off a disagreeable odor of decay. This is what has happened. The bacteria of various forms which, in the dried condition were clinging to the hay, or which were in the water, have multiplied to such an extent that they made the water turbid, and many of the mobile forms have sought the surface, where the oxygen was most abundant. The solution of organic material from the hay has furnished an abundance of food, and as the bacteria have torn this into simpler forms to get the 
particular elements which they needed for their own use, the freed material, in part in the form of bad-smelling gases, has either been set free into the air or remains absorbed in the water.

If you examine a tiny droplet of the water from time to time with the microscope, you will find that it is swarming with various forms of bacteria, rods, balls, and perhaps spirals, many of them in active motion. But you will notice that from day to day the prevailing forms change. One day the little rods will be most abundant, the next these may have largely disappeared, and perhaps the little balls are the most common forms. Then perhaps a new set of rods or balls will appear of a different size from the first. After a while you will find that the bottom of the jar has become covered with a light-colored sediment, and the water has become clearer.

The bacteria of one form or another have gone on dividing and subdividing, breaking up the dissolved organic matter in the water until either they had used up the special form of material which was best suited to their needs, 
or until the material which they had set free had so far accumulated as to prevent their further growth, and then they died, self-poisoned, just as a man might who should be shut up in a tight room until the accumulation of the products of his respiration and excretion had made further life impossible. Or they may die because other species of bacteria growing in the same fluid furnish material which poisons their neighbors. So the procession of life goes on, until the bottom of the jar becomes a veritable graveyard of races.

Some forms of the bacteria, however, which seem dead, and fall with the rest to the bottom of the jar, are really only in a resting stage; they have formed spores within themselves in the manner described above, and may lie dormant until the proper conditions come again, when they may spring into renewed activities. But new species may from time to time fall into the jar from the air and find in the water, which was rank poison for the dead species at the bottom, just the food they need, and so will the drama of life and death be enacted anew for long periods. 
In such a confusing mixture as this the student finds it no easy task to make out much except differences in form and movement, in the jumble of tiny plants. What he needs to do is to get each species by itself, so that he can cultivate it alone, and find out what it is and does under more simple conditions.

The device which was formerly in vogue, and which was called the fractional method of separation, was to make some beef-tea-which is pretty good food for most bacteria,-and putting a little of this in a great many separate little tubes, carefully heat them so as to kill all the bacteria which might by chance have been in the flasks or in the materials from which the beef-tea was made. The investigator also takes a large flask of water and kills by heating all the bacteria which it may contain. Now he dips the end of a fine needle, which has just been heated red-hot to kill the omnipresent germs, into the putrefying mixture. He rinses off the invisible amount of material which clung to the needle into the pure water in the large flask, and thoroughly shakes it so that the bacteria which he has put into it may become equally distributed through it. 
He calculates that the bacteria which he has thus put into the large flask of water will have been so much diluted and separated that, if he now dips a needle into this water, or takes out a small drop, and rinses it off into one of the tubes of beef-tea, and does this for each one of the several beef-tea tubes which he has prepared, into some of them he will have introduced, small as they are, only one single individual bacterium.

He now sets his beef-tea tubes away in a warm place where no accidental contamination can occur, and lets them stand until the fluid begins to get turbid. Now, by a careful microscopical examination he can tell whether one or several forms of bacteria are growing in his tubes, and if in any of them only one form is present he has succeeded, and has what he calls a culture of some particular bacterial species. This he can study at his leisure, plant and replant it in fresh beef-tea tubes, and find out to a certain extent what its habits are, what new chemical substances it produces as it feeds itself from the beef-tea, etc.

But this is a long and wearisome process and somewhat uncertain in its results too, 
because one can never be quite certain from a microscopical examination of small portions of a beef-tea culture, but that in some other part, for he cannot examine it all, other forms of bacteria may be present.

Nowadays, although we find beef-tea very useful on many occasions in cultivating the bacteria, we most frequently make use of solid foods.

Boiled potatoes, which have been carefully cleansed and sterilized-that is, free from any bacteria from the soil or air-by steaming, are usually first prepared. These are cut in halves, with knives sterilized by heat, being held in the fingers which have been freed from living germs by washing with corrosive sublimate, and placed under sterilized bell-jars or in tubes, so that they may not be contaminated by the accidental falling upon them of bacteria from the air. Now, by means of a platinum wire set in a glass handle, which has been sterilized by heating to redness, a tiny bit of the bacteriacontaining material is conveyed to the cut surface of the potato, and the latter is covered again and set away for a day or two in a warm 
place. Usually at the end of this time, if all goes well, there will be a growth of the bacteria on the potato so large as to be quite visible to the naked eye. This growth, or "colony," as it is called, which is made up of myriads of individual bacteria, the offspring of those planted, in many cases presents very characteristic ways of growing or special colors, etc., characters often by which particular species of bacteria may be distinguished from all others, even without the aid of the microscope. This gross appearance of the growing colonies is useful in the recognition of species which under the microscope look very much alike. Just as in agriculture, if one were in doubt as to two specimens of seed which closely resembled one another-say turnip and rape, for example-by sowing them in the ground and observing the resulting plants, all doubt would be removed.

In thus planting the invisible and minute bacteria, and allowing them to grow until such large masses of colonies are formed that we can readily see and study them with the naked eye, we are realizing in another field a project 
which was urged with a good deal of persistency some years ago for finding out if there were inhabitants in the moon, and for communicating with them.

It was proposed to build in outline on some great plain on the earth's surface, like that of Siberia, a gigantic structure so large that even assuming that the lunar inhabitants had no telescopes, it would be visible to them. This structure was to have some simple suggestive mathematical form like a circle or triangle. Seeing such a thing appear on the earth's surface, it was thought that the lunar inhabitants would probably "catch on"-this phrase was not known in those primitive times-and erect a similar structure, and thus communication would be established. The moon project fell through, but as we have seen by a somewhat similar device, we actually make the inhabitants of an unseen world communicate to us to-day some of the secrets of their hidden life.

But the knowledge derived from the mode of growth of bacteria on potatoes is limited, because as the potato is opaque we can see only the surface of the colony; and, further- 
more, not all the bacteria grow well on potatoes, and some do not grow upon them at all. So the next step is to make some transparent solid substance which shall be a suitable soil for bacterial growth. One of the most common and useful substances for this end is a Io per cent. solution of gelatin which is mixed with beeftea, pepton, and a little common salt, and then made neutral or slightly alkaline by carbonate of soda. This mixture, carefully heated so as to destroy all bacteria which might be present in its ingredients, is filled into ordinary glass test-tubes which have been sterilized by a high temperature. These are filled about one third full of the gelatin mixture, and the opening is stopped by a plug of cotton batting. Through a long plug of cotton, bacteria cannot pass; the air can enter and leave the tube, but all bacteria are caught by the fibres of the cotton. After the gelatin has become cool and solid, by means of a sterilized platinum wire, some of the bacteria are introduced into the gelatin, the cotton plug being removed for an instant for this purpose. Being transparent, the gelatin permits us to see from the sides as well as 
from the surface the exact mode of growth of the particular form of bacteria introduced into the tube, and thus we learn a new set of characteristics for the different species.

But if we need to keep our bacteria at a higher temperature than that of an ordinary room, say at the temperature of the body, at which alone some forms will grow, the gelatin would melt and the bacteria would be scattered through it, and the characteristic mode of growth of the masses or colonies would be lost. So, for this purpose we use, instead of gelatin, Agar-Agar, a material derived from a sea-weed, which in one per cent. solution forms a gelatinous solid transparent mass, which may be heated to above the temperature of the body without fluidifying. To this are added, as to the gelatin, beef-tea, pepton, etc.

By the use of these various soils, or "culture-media," as they are called, we can arrive at a series of characteristics in the mode of growth of various bacteria by which, together with their form when seen under the microscope, we can distinguish them one from the other, just as the naturalist distinguishes from each other nearly related animals and plants. 
It is obviously of the greatest importance, as we have seen above, that we should be able to separate different species of bacteria from one another in the living condition, so that we may have growths or colonies which shall contain one species alone without admixture with any other. These are called "pure cultures." This is by no means an easy task, as will be appreciated when we consider how exceedingly minute the organisms are, and how much danger there is that the bacteria floating everywhere invisibly in the air, may become mixed with those forms which we are studying. By a very simple device elaborated by Dr. Koch, of Berlin, we are, nevertheless, able at any time to separate one species from another with the utmost certainty, or from a mixture of many species to get into separate tubes pure cultures of each species by itself. This is accomplished by what is called the "plate culture," the details of which are as follows: Suppose we have a mixture, say a sample of impure drinking water, which contains four different species of bacteria, which we wish to get into pure cultures in separate tubes. 
We mix thoroughly a small amount of the bacteria-containing water with a much larger amount of the above-described nutrient gelatin, rendered just fluid by heat. Then we pour this mixture out onto a glass plate which has been carefully sterilized by heat, so as to form a thin layer, which soon cools and becomes solid. The glass plate is now covered with a bell-jar to prevent the access to it of any bacteria which may be floating in the air, and to prevent its drying, and set it away at the proper temperature. The individual bacteria which were scattered through the gelatin layer will presently commence to grow.

After a few hours or days, as the case may be, if we look at the gelatin-film we see, sometimes with the naked eye, sometimes only under the microscope, little points or masses scattered through the gelatin, which are colonies of bacteria, each one consisting of hundreds or thousands of the organisms which have grown from the single organism which was fixed at that point as by a solid wall when the gelatin cooled.

Of course, it sometimes happens that two or 
more of the original germs either of the same or different species were solidified in the gelatin when it cooled at the same place, and then the resulting colony will consist of all the organisms which have grown at this point, mixed together or growing closely side by side. In most cases, however, the little colonies are composed of the descendants of a single germ, and if we put the gelatin plate under the microscope we can see the different forms of the colonies which have grown from the different species. The differences in the mode of growth of the bacteria when planted and studied in this way are manifold; some are colored, red, green, yellow, orange, violet, brown, etc.; some are colorless, some have sharply defined smooth edges, some are jagged or fringed, some are beaded, or send out little spines; some cause the gelatin in their immediate vicinity to liquefy, so that they come to lie in a little pool of fluid in a pit or depression in the solid gelatin.

Now, by examining the plate microscopically we cannot only see how many different forms of colonies there are-and each different form 
of colony indicates a difference in the species of bacteria composing it,-but nothing is simpler than, directly under the microscope, to take out on the tip of a sterilized platinum wire little bits from each one of the different forms of colonies, and transfer them to separate tubes of gelatin. Thus we secure "pure cultures" of all the different forms of bacteria which were contained in the original mixture. Thus, minute as the individual bacteria are, lying far below the power of unaided vision, we are able to manipulate them with as much certainty as the agriculturist does his larger plants.

When we have thus got different species of bacteria separated from one another in the form of pure cultures we can experiment on them in many ways, and learn their varying characteristics. We can plant them under such conditions that their oxygen supply is limited, and learn whether they do or do not thrive; we can see whether they grow best at high or low temperatures, and what degrees of heat or cold will kill them; we can grow them in large quantities, and study the chemi- 
cal compounds which result from their life processes. We can apply to them various chemical substances which are called germicides, or disinfectants, and find out to which of these and in what strength they most readily succumb.

In this way a large number of different species of bacteria have been studied, and these have been arranged in groups which have some characters in common. So that already, although the study of the bacteria by the new methods is of very recent date, we have the outline of analysis tables, something like those made for the identification of the higher plants in Gray's "Botany," for instance, by the use of which the student can identify certain of the better known forms which he may come across in his studies.

The nomenclature in bacteriology is still in a rather chaotic condition, but a beginning has been made. The term bacteria (singular, bacterium) applies to the whole class of organisms of whatever shape. They are also sometimes called "germs." Micrococcus is the generic name of the most common forms of the spher- 
oidal bacteria. Thus there is a species of micrococcus which produces a yellow color when it is growing in masses. This species is called Micrococcus luteus. There is another species of micrococcus which when growing has the peculiarity of a grouping of the micrococci, or cocci, as they are sometimes called, in fours; this species is called Micrococcus tetragenus.

Another genus among the spheroidal bacteria is called Streptococcus, because the little balls tend to cling together and form longer and shorter chains as they grow. Then among the rod-shaped bacteria the most common genus is called Bacillus (plural, bacilli), and some of the species of this genus are among the most common and abundant forms.

'Thus with a temporary and provisional system of classification, the work of studying and describing the bacteria is steadily going on. And if to see and describe living beings on which no human eye has ever rested before be satisfying, it will be long before the sighs of bacteriological Alexanders are heard in this unseen world, whose very shores have been barely touched by the new explorers. 


\section{CHAPTER IV.}

SOME BACTERIAL CURIOSITIES.

N OST travellers, and some people who stay at home, too, have now and then been mystified and delighted, when not frightened, to see in the night-time that wavering, cold, uncanny, but beautiful light, sometimes tinged with the most exquisite green or blue, which is commonly called phosphorescence. Sometimes it is seen in decaying plants or wood; sometimes bays or inlets of the sea are fairly luminous with it. The surface of dead fish and of meat and various kinds of vegetables often become so bright as to illuminate the storage rooms in which they lie.

Some time since there was brought to the laboratory for examination a cluster of sausages which had been destined to grace a boardinghouse breakfast-table. To the consternation of the maid who went into the dark cellar 
for them in the early morning, there hung in the place of the sausages a fiery effigy which seemed to her more like the quondam spirits of their mysterious ingredients than the unctuous homely friend of the homeless boarder.

The explanation of this is now simple enough without recourse to the supernatural ; for it has been recently shown that this curious light which various organic substances emit is due, in many cases at least, to the enormous numbers of certain kinds of bacteria which are present on their surfaces, hard at work feeding on the organic compounds which are present and undergoing decay. Pure cultures of these singular bacteria have been made and cultivated in considerable quantities. These bacterial masses, together with the tubes in which they were growing, have been placed in a dark room with an open watch beside them, and bacterial masses, tubes, and all actually photographed by their own light, the pointers of the watch showing distinctly the time of day. So it would seem that this cousin of the will-o'-thewisp-no doubt often mistaken for him-is no malevolent genius after all, but a quiet little 
citizen working away as diligently as he can to make the world more comfortable for his betters.

It has long been known by the makers of beverages that alcohol is formed in certain sugary mixtures by a process called fermentation, and that this tearing to pieces of the sugar into other compounds, one of which is alcohol, is accomplished by a little living organism called yeast, closely related to the bacteria. In the earlier days of beer-and winemaking it was often found that the beer did not work or ferment properly, and that wine would get sour or bitter. We now know that these irregularities are due to the fact that certain kinds of bacteria are apt to get into the wine or beer during the manufacture, and when they do a bitter struggle for food goes on between the yeasts and the bacteria; or the latter may bide their time, and later in the process begin to grow and produce very undesirable compounds in the fluids. So the manufacturer has to be on the alert, and at the right moment come to the rescue of his army of servitors, the yeast plants, and introduce 
into his beer some chemical substance which is innocuous to them but deadly to the intruding bacteria. Or he may raise his wine at a certain period to such a temperature as will suffice to kill the bacteria but not injure the flavor of the already fermented juice. Here for the first time we see the bacteria coming in conflict with the purposes of their earthneighbor-man.

Some of the bacteria are great lovers of oxygen, and if they are shut up in a little cell containing a few drops of water in which a bubble of air has been enclosed, after a while it will be found that those forms which are cavable of locomotion have made their way from all parts of the fluid, which is a veritable ocean to them, and are closely clustered around the air bubble, jostling and bumping against one another in the most reckless way. It seems almost as if this rush towards the oxygen were an evidence of volition in its simplest form way down on the lowest border-line of life.

Some forms of bacteria are exceedingly invulnerable to the action of cold, and can not only move actively about in very cold water, 
but can remain alive for long periods fast frozen in a mass of ice. Now a very curious thing has been noticed in the ice which is gathered in these regions and which we use for domestic purposes, and that is, that the socalled bubbly streaks which we usually see in our ice blocks contain, as a rule, many more bacteria than does the transparent ice close by.

It has been found, on cultivating the bacteria from the bubbly streaks, that the species which was most abundant here is an oxygen lover, and is also very mobile. Now the bubbles which collect in streaks or layers in the ice collect during the daytime, or when the ice is not freezing very fast below, and there is time for the air-seeking bacteria to gather around them in great numbers. But now, when a clear night or a cold snap comes on, the ice closes around both bubbles and bacte. ria, and we have formed, to use the language of the geologist, an air and fossil-bearing stratum. Only our bacterial fossils are not dead, and all we have to do in order to find out what forms of life were present in our successive geological periods, limited perhaps 
only by a night, is to melt a bit of the ice, mix it with our culture gelatin, and in a day or two we shall have a whole garden of growing plants, which we can study at our leisure.

Among the most curious things which the bacteriologist has to exhibit in his bacterial conservatory is the color-forming species. It is only when they are growing in masses, of course, that enough color is formed to be visible; but then one may see in the little slimy masses which cover the surface of the food or culture media in the tubes, every color of the rainbow and many variations in hue. Sometimes not only is the bacterial mass itself brilliantly colored, but some of the chemical substances which they form as they grow permeate the gelatin and give it a beautiful fluorescence, green or red.

The writer was not long ago standing beside a supper-table, whose sole floral decoration was a bunch of large, exquisitely tinted chrysanthemums, when a friend remarked upon the patience and skill which had been required to develop this magnificent flower by artificial selection from its simple and homely ancestor, 
and queried in a quizzing way how long it would be before somebody would be trying to modify the colors of some of the bacteria by the well-known horticultural methods. His idea was a clever one, but he was behind the times, for already a German bacteriologist had, starting with a deep purple-forming species of bacteria, and selecting and replanting the lighter-colored colonies, at last obtained cultures which were nearly white, but were in other respects essentially the same. Thus the great and far-reaching principles of natural selection, in accordance with which life, slowly emerging from its primeval simplicity, at last came to be manifested in that grand scale of living beings at the top of which man stands supreme, are still to be traced way down among the invisible organisms which typify the earliest and simplest expression of life.

But certain of these color-forming bacteria are sometimes very disagreeable intruders upon domestic life. Occasionally, without warning, the milk of a particular dairy suddenly develops a very uncanny deep-blue color, which, like an epidemic, spreads to all 
the milk which is stored in special rooms. This occurrence, for a long time a disagreeable and costly mystery, is now known to be due to a tiny bacterium of the genus Bacillus, which. floating about in the air with the dust, from time to time infects rooms, and, falling into the milk, grows there, producing the blue coloring matter.

Sometimes milk gets red instead of blue, and then the change is due to another form of bacteria floating with the dust. Bread, too, may become infected in the same way, and the dough set aside in bake-shops overnight to rise has not infrequently been found in the morning resplendent with colors which fairly rivalled those of the rising sun.

There is a species of bacteria in every good collection, and a veritable Nestor among the forms known to man, which has a curious ecclesiastical history. Among all the innumerable natural phenomena which, by their striking character, infrequent occurrence, and lack of apparent cause, were in early times relegated to the domain of the supernatural, none perhaps was more strange and uncanny 
than the sudden appearance on the moist surfaces of articles of food of little bright-red shiny droplets, which, gradually spreading, at length formed large shiny, deep, rich-red masses, looking very like drops, or masses, or clots of blood. The story is long and tragic of the dire calamities, unmentionable crimes, and swift retributions which these strange appearances of blood were supposed to foreshadow.

This miracle of the bleeding Host has appeared again and again in the hands of the priestly defenders of the faith as a most potent evidence of divine intervention with the affairs of men. The consecrated wafer placed overnight in the moist and bacteria-laden air of the church edifice, would in the morning be found besprinkled with bright-red drops. What could it be but blood? No human hand could have come near the place, and so what else could be believed but that it was from the hand of God? It was one of those early miracles in which both priest and layman could alike share in believing with perfect honesty. The divine finger pointed, but to 
what, it was the office of the priest to say. How many lives were sacrificed and homes destroyed through that most honest of ecclesiastical delusions, the miracle of the bleeding Host, it were useless now even to conjecture.

To-day we cultivate in our tubes the tiny bacteria which, growing in masses, made the drops of blood, and the last elements of romance and tragedy seem to disappear from the story as we name them-Bacillus prodigiosus.

There are some species of bacteria which are mortal enemies and cannot live together, one species killing out the other almost as soon as they come in contact. The details of this invisible mimic warfare we do not yet understand, nor do we know what are the weapons with which it is carried on. It is probable that it is in virtue of some poison which they form as they live and grow that the victors gain possession of the field.

On the other hand, there are two or three instances of a sort of one-sided Damon-andPythias story among these creatures; for in the attempts to isolate the species by culture it 
has been found that sometimes two species can be isolated and grow together, but if the attempt be made to separate them, one of them always dies. The exact nature of this friendly tie is still unknown. Perhaps in this case the material which is set free by one species as it feeds and grows is the only thing which its associate can live and thrive upon. 


\section{CHAPTER V.}

THE BACTERIA AS MAN'S INVISIBLE FOES.

TE have seen that the bacteria in general are not only curious and interesting as objects of study, but in the work which they are ceaselessly and silently doing they are absolutely indispensable to the continuance of the higher forms of life upon the earth. But unfortunately there is another darker side to the picture. Among the myriads of useful as well as harmless bacteria, we have lately learned that there are a few forms which find the most favorable conditions for their life and growth in the bodies of men and some of the higher animals.

They do not grow well in nature as other bacteria do, nor do they thrive on ordinary decomposing organic matter. They look very much like the more common harmless bacteria, some being little balls, some rods, and some 
spirals. Like other bacteria, they grow at the expense of the materials with which, under favorable conditions, they come in contact, and like them they produce new chemical compounds as the result of their life processes. When they get into the human body, the different forms grow in different ways, and produce different kinds of chemical compounds, and this growth or the poisonous chemical compounds which are produced cause disease.

Bacteria which can grow in the body and produce deleterious effects there are called pathogenic or disease-producing bacteria. The poisonous chemical compounds which they set free as they grow, are called ptomaines.

Now, before we try to comprehend how disease can be produced by bacteria, we ought to understand what disease is.

We have seen in the first chapter that the human body is made up of several communi ties of cells, each community having acquired the power of doing some special thing for the good of the body as a whole, and that these cell communities are all co-ordinated so as to act in harmony. We have seen that these 
cell communities which make up this wonderful mechanism are all originally derived from a single living cell, the ovum.

What this mysterious thing is which we call life, which from the original cell, the ovum, is imparted to all the myriad specialized cells which spring from it as the body grows; what it is which determines that from one of two cells which under the most powerful of microscopes look exactly alike there shall develop a man, and from the other an animal, we simply do not know. We theorize, we speculate, we draw analogies, we give names, but at the end we conclude that we must wait still for more light. We do know, however, that this self-built cellular mechanism, the body, which is alive, has in it the power of self-renewal: the power, when once started, to go on doing the various things for which it is fitted for a certain time, provided that the proper external conditions are maintained. But sooner or later the machinery begins to creak and tremble, sometimes in one part, sometimes in another, sometimes everywhere, and gradually or suddenly that combination of activities 
which we call life disappears, and the worn-out mechanism for the first time since it came into being is still. This is death. There is no disease, but, as we are apt to say-not because it means much, but because we think we must say something, - an exhaustion of the vital forces. The mechanism is worn out, and so can no longer develop out of food and air the self-renewed impelling force. It is death from old age. But this is comparatively infrequent.

If the proper food, air, and surroundings are maintained, the various co-ordinated cell communities which we call liver, brain, kidneys, lungs, integument, and so forth, provided they are properly set going in the first place, have not only the power to go on doing their work, but they have a well marked capacity for overcoming and resisting deleterious agencies of one kind and another,- - a sort of health inertia. The muscle cells do make shift to contract even though their food supply be temporarily scanty; the blood cells will carry a certain amount of oxygen in their ceaseless rounds of visits to the tissues, though the air from which they get it through the lungs be as foul and 
meagre as it is in some of our fashionable theatres and churches and school-rooms. And if certain cells or groups of cells should be forced to work awry, they always tend to get back to their proper work and conditions even against great obstacles, just as soon as they can.

Even when large numbers of cells or cell groups are entirely removed from the community, as by an injury, new cells can form out of those which are left, or the duties of the lost cells are assumed and may be permanently maintained by their fellows. Patriotism and esprit du corps are very markedly typified in the cell communities of which our bodies are made up.

When important cell communities are seriously injured or changed in structure so that they cannot do well the things which they ought to do, or when they fail to act in harmony, through some fault of their own or some disorder in the co-ordinating mechanism, the failure in what we may term the rhythm of the body's activities constitutes what we call disease. The part which may be the seat of the dis- 
ease is as varied as are the organs and tissues of which the body is composed.

The disturbances in the activities of the body which result from these changes in the structure and action of the various parts have been so long studied that the educated physician is usually able to tell from certain irregularities of the body's activities what part or parts it is which are affected. In many cases the physician does, in some he does not, know what the exact cause is of the disturbance. In some cases, when the cause of the disturbance is known, he can remove it either by directing a change in the habits or by the administration of drugs, and then the tendency of the cell communities of the body to get back into their proper condition of themselves alone will restore health. Sometimes this inherent tendency is aided by the use of medicines. Some of the body's disturbances tend to pass away of themselves after a longer or shorter period, if they are not so severe as to destroy life. Under these conditions the duty of the physician may be only to aid the body by food and stimulants in the work which it is doing itself. 
And so through the long list of ills which come upon the human frame from known or unknown causes the wise physician guides and aids the natural recuperative tendencies of the body cells.

Among all the varied changes in structure and disturbance in activities of the body which thus constitute disease there are, as we have seen, several, and these most important ones, which have recently been proven to be caused by bacteria. To some of these we must now turn our attention so as to learn how the disturbances are brought about, and what we may do for ourselves to avoid them. 


\section{CHAPTER VI.}

THE BACTERIA OF SURGICAL DISEASES.

ONE of the greatest dangers associated with injuries and wounds of the body, whether inflicted by accident or made by the knife of the surgeon in necessary operations, is the liability to what is known as blood poisoning.

So great is this danger, that it has long been known that in war a great many more lives are lost from blood poisoning than by bullets or cannon-balls. The cause of this form of disease, which is so apt to complicate wounds, was for a long time entirely unknown. Then, as these wounds were apt, in blood poisoning, to be foul and bad-smelling, it was concluded that the trouble might be that dirt or filth of some sort got into them and so set up the disease.

What the particular thing was, whether 
bacteria or something else, which so gained entrance to the body, no one knew. But the surgeons did not wait until they should know all about the cause of the trouble, but began to apply to the wounds such materials as would actually kill germs, or, at any rate, keep the wounds free from putrefactive changes. Carbolic acid, dissolved in water, was found to be efficient in this way in washing the wounds.

Then, as it seemed more and more as if the trouble were due to living germs falling upon the wounds from the air with the dust, it became the practice, when surgical operations were being done or wounds dressed, to spray carbolic in the air about the operator's hands and over his instruments and upon the wounds, and when the bandages were put on to seal them in tightly, so that no germs could gain access to the wound while the healing went on. All this time the particular species of bacteria which produced the trouble remained entirely unknown; indeed, it was only an hypothesis that the disease was due to germs at all.

A great deal of careful laboratory work has, 
however, been done recently on this subject, and a great many animal experiments made, until now we know not only that blood poisoning but abscesses, erysipelas, and many other less serious inflammations are caused by bacteria. We have found out, furthermore, that there are two particular species which cause the trouble in the great majority of cases.

Both of these bacteria are little balls or micrococci. One of them, as it grows, tends io form chains, and so is called Streptococcus ; the other tends to group itself in clusters a little like a bunch of grapes, and so is called Staphylococcus.

Now, it has been further found that these two forms of bacteria are quite abundant where people are gathered, mostly in dirty places ; sometimes where the healthy, but especially where sick people are crowded together, as in hospitals, They are found in small numbers floating with the dust in the air, where dust lodges, and often in the mouths and on the clothing of the people themselves.

It is thus evident how the wound diseases, such as blood poisoning, can come about, for 
wherever the dust falls on the open surfaces of the wounds or on any thing which comes in contact with them, and the living bacteria lodge, they may, if not destroyed, commence to grow, and not only by the poisonous materials which they form as they grow, interfere with the healing of the wounds, but they may get into the blood and be carried to various parts of the body, there growing and producing sometimes fatal results.

It is one of the greatest practical triumphs of science in modern times that the surgeon can now so carefully plan out his operations and treatment of wounds, that not only is blood poisoning, as it used to prevail but a few years ago, the greatest rarity among educated and skilful surgeons, but the most extensive operations, such as opening the great cavities of the body, may now be done, when they are necessary to save life or make it endurable, with very little risk of the frightful dangers which formerly attended such procedures.

Childbed fever, which in former times claimed so many victims under especially lam- 
entable circumstances, and which used sometimes to spread with frightful rapidity among women whose confinement took place in hospitals, is now of comparatively rare occurrence, because the educated physician knows what the particular element of danger is and how to avoid and combat it. For it has been found that childbed fever is really a form of blood poisoning, due to the same germs as induce the disease in ordinary wounds.

Dr. Oliver Wendell Holmes, early in his career, became convinced that the poison causing childbed fever could be carried on the clothes of the physician from one patient to another. What the poison was he could not even fairly conjecture, but of the fact he was certain. In spite of much opposition and ridicule he urged his views, and many lives were ultimately saved and epidemics stayed because of his persistency in making known his facts. To-day we not only know that all that he urged was true, but the poison which he assumed but could not see has been proved to be bacteria, and we can now cultivate them in tubes and know exactly what will most 
surely destroy them. While literature owes much to the wit and cleverness of the genius of the breakfast-table, science and humanity are not less debtors to the zeal and pertinacity of the young doctor, who still declared for his beliefs, though his more aged and then more renowned confrères applied to him many terms of opprobrium and disrespect.

Now let us look a little more closely at the way in which these tiny organisms cause inflammation, suppuration, or the formation of pus and blood poisoning. We have seen in the first chapter that although most of the cells of the body have assumed special forms and powers as the body develops out of its embryonic stage, there are some cells which scarcely seem to have got beyond the stage in which the simplest of the unicellular organisms, such as the amœba, belong. The most prominent of these lowly organized cells in the body are the white blood-cells or, leucocytes as they are called. Under ordinary conditions they go circling round the blood-vessels along with the red blood-cells, or, crawling out of the blood-vessels, slowly make their way around 
in the smaller spaces in the tissues. Exactly what they do under these circumstances we do not know. There is some reason for thinking that they act to some extent as scavengers, and when they come across a particle of worn-out or foreign material in the tissues, take it into themselves, just as amœba does its food in water, and either digest it or carry it back to those parts of the body in which waste material is systematically disposed of.

But let an injury such as an open wound occur, and the whole attitude of these leucocytes changes. They get out of the bloodvessels with all speed, in greater or less numbers as the occasion may demand, and gather about the edges of the wound, and after a time they, together with some other cells of the injured tissue, change their shape and character, and actually form, with the aid of the blood-vessels near-by, a mass of new tissues, which replaces that which was lost by the injury, and so permanently binds the edges of the wound together. Sometimes these white blood-cells gather in much greater quantities about the wound than is necessary, and then 
they are thrown off in the form of a material which we call pus.

Now to come back to the bacteria which we are studying. When these bacteria get into the tissues, they may begin to grow, and as they do so they produce a small amount of a poison which we call a ptomaine, and this poison acting injuriously on the tissues where it is formed, the white blood-cells gather about it just as they would about a wound. If the bacteria continue to grow and multiply, the white blood-cells may accumulate more and more and die, the tissues may break down, and so an abscess may be formed. Sometimes the germs get into the blood and are carried to various parts of the body, and wherever they lodge abscesses may be formed, and this constitutes one of the most dreaded forms of blood poisoning.

Now what do the white blood-cells accomplish under these circumstances? Many believe, although the matter has not been quite settled yet, that when these bacteria get into the tissues and begin to grow, the arrival of the white blood-cells upon the scene signalizes the $x$ 
commencement of a life-and-death struggle between the bacteria and the cells. The cells attempt either to swallow and thus kill and digest the bacteria, or to so closely surround them as to cut off their oxygen and food supply and so destroy them. The bacteria, on the other hand, so long as they can grow and proliferate, produce a poison which may kill the white blood-cells and break up the other tissues round about.

There is much reason for believing that this is what actually occurs: that the resisting capacity of the body to the incursions of these invisible organisms is largely resident in these lowly organized cells, which in carrying on their simple cellular activities assume the role of defenders of the body against the bacterial invaders. If the conditions are favorable for them the white blood- and other cells may get the upper hand of the bacteria and stop their growth or kill them all off and thus avert the danger. If, on the other hand, the cells are not vigorous enough to resist the poison eliminated by the bacteria and themselves succumb to its influence, the way is opened to the spread of the infecting germs. 
It sometimes happens that so extensive a growth of the bacteria occurs in some local region of the body and so much of the soluble poison is produced that although the bacteria may not themselves get generally distributed the poison which they furnish may enter the circulation, and so produce in distant parts of the body most serious disturbance or even cause death. These bacteria apparently do no harm when they lodge upon the uninjured surface of the body, but only when they get into the tissues through an injury or lodge upon surfaces of the respiratory or digestive tract which are already the seat of disease.

This is in brief the story of the bacteria which most commonly produce the common inflammations of the tissues, the complications in the healing of wounds, and the varying phases of blood poisoning. As pus in greater or less quantity is apt to be produced under these circumstances, these bacteria are called the pus-forming or pyogenic bacteria. Some other bacteria may occasionally produce similar effects, but those which have been described are the most common and important. 
The effects which these as well as other disease-producing bacteria may produce in the body vary considerably under different conditions. Sometimes the general condition of the body is such that it seems to furnish very favorable soil for their proliferation or is especially vulnerable to their action. Sometimes the particular germs which gain access seem to be especially virulent, perhaps from their inherent vigor or from conditions which we know nothing about. We are in these diseases dealing with poisons of the human body, but with self-propagating poisons which from an almost infinitesimal amount may grow to such quantities as will fairly overwhelm the body. 


\section{CHAPTER VII.}

THE BACTERIA WHICH CAUSE CONSUMPTION, OR TUBERCULOSIS.

M ORE than one seventh of all the people who die are carried off prematurely by consumption, or tuberculosis. But it is only within the present decade that we have had any definite knowledge as to the cause of the disease. For a great while physicians have known a great deal about it. They have become very expert in detecting its advent and in tracing its course, and came long ago to know but too well whither it tended. The disease was usually regarded as hopeless, and its treatment was entered into rather for humanity's sake than in the expectation of inducing a cure. To-day the aspect of affairs has greatly altered. We know that tuberculosis is caused, and caused alone, by exceedingly minute, rod-shaped bacteria, which, in 
one way or another, gain access to the body. When there, if the conditions are favorable, they tend to grow, and as they do so there form about them little masses of new tissue, which are called tubercles. The most common seat of the disease is the lungs, but it may occur in any part of the body.

It is not necessary for our purposes to enter further into the details of the progress of the disease. It is but too well known to nearly every one who has seen one and another pass away from sight under its insidious progress. It is our purpose here only to show how the disease is commonly acquired.

Not all persons are equally liable to be attacked by tuberculosis. There seems to be a certain condition of the body cells which predisposes to the disease, and this predisposition is in the most marked degree hereditary. We do not know yet in what this predisposition consists. We believe that when the tubercle bacillus gets into the healthy body the cells of the part in which it lodges in some way tend to resist its growth, or afford unfavorable conditions for its development. The temporary 
hypothesis around which we try to crystallize our accumulating knowledge is that in hereditary predisposition to tuberculosis this inherent resisting capacity of the cells to the incursions of the germs is in some way diminished. This is very indefinite, it is true, but it is the best we can do at present. We know that tuberculosis is never caused by any other thing than the tubercle bacillus, and that even in persons predisposed by inheritance or otherwise to the disease it cannot occur unless this particular germ gets into the body from outside. The germ itself has rarely, if ever, been shown to be directly inherited. If, therefore, we could keep this particular germ away from human beings, there would be no more tuberculosis, no matter what the inherent tendencies of the individual might be.

Let us now see what our knowledge teaches us as to the sources of infection with the tubercle bacillus. In the first place, we should not forget that as the early stages of the disease are often very insidious in their progress, and as an individual may actually have a moderate degree of tubercular disease for a 
long time without the slightest disturbance of the general health, and, furthermore, as the germs in greater or less number are widely distributed in densely inhabited regions, it is usually quite impossible to say in any particular case what the source of the infection was.

Cattle, in this as in many other countries, are very frequently the victims of tuberculosis, which is caused by the same germ as is the disease in man. As the living tubercle bacilli may be contained in the milk from diseased cows, and in the flesh of affected cattle, it appears that here is an important source of danger.

It is almost inconceivable that any man not wholly given over to the spirit of the Devil should be capable of sending into the market meat from tubercular cattle, if he is aware of it. Yet there is reason for believing that a very considerable amount of such diseased meat is actually sent into our large towns every year, with the full knowledge of some of the unscrupulous dealers, and probably consumed, usually by the poorer and more ignorant classes. Thorough cooking of such 
diseased meat would kill the bacilli, but a large amount of meat is everywhere commonly consumed uncooked, or but partially cooked, in the form of sausages or other minced messes.

Infection with the tubercle bacillus in the intestinal canal is not so liable to occur as in some other parts of the body, even among persons predisposed to the disease. But, nevertheless, the danger from tubercular milk and meat is a very real and a growing one.

The most frequent seat of affection with the tubercle bacillus is the lungs, and the most common way in which the germs gain access to the respiratory passages is by being breathed in with the dust which is floating in the air in rooms or regions where tubercular persons have been. In other words, tuberculosis is most commonly acquired by indirect transmission of the tubercle bacilli from man to man through the dust of the air.

Now the most common way in which the tubercle bacilli get into the air from consumptive people is this: the little masses of new tissue which form in the lungs where the tubercle bacilli are, are not well supplied with 
blood, and for this and other reasons they are apt to become friable and break down, and then little particles of them are apt to be coughed up and discharged in the sputum. But this broken-down material frequently contains large numbers of living tubercle bacilli. Now, if the material which consumptive persons cough up and spit out were always destroyed at once by being burned or received into a dish of carbolic acid or some other efficient disinfectant or germicide, one of the greatest dangers of the spread of the disease would be removed. But unfortunately this is in fact very rarely done. Thousands of consumptives are walking about the streets of our large towns or visiting places of assembly, who discharge the infectious material coughed up from the lungs upon the pavements or floors. This dries, and shortly is ground up, and takes its place among the rest of the floating dust of the air.

Essentially the same thing takes place in rooms in which consumptives are confined if intelligent precautions are not taken to destroy or convey away the discharged material. It 
has been found by actual experiment that a considerable number of living tubercle bacilli may be lodged, together with other clust particles, high up on the walls of hospital wards in which consumptives are unintelligently cared for, in situations to which they could have been conveyed only through the air as ordinary dust is. The same material allowed to dry on handkerchiefs may in a similar way become a source of danger, not only to others, but may cause a fresh infection of the patient himself.

It is very important to remember that it is only when this discharged material is allowed to dry that it, under ordinary circumstances, becomes a source of infection through the air. Bacteria never rise from thoroughly moist surfaces. One might spread a thick layer of living bacteria of any kind, no matter how infectious, over an exposed surface, and, provided it was kept thoroughly moist, might breathe with impunity the air sweeping in strong currents over it, because the germs always cling most tenaciously to such surfaces. Of course a current of air strong cnough to 
sweep the particles of fluid bodily off from their position would be efficient in spreading the infection. The important point which this statement emphasizes is that the breath of tubercular persons is not infectious; the air itself passing over the moist surfaces of the respiratory passages and the mouth carries no germs. The act of kissing, however, might lend itself most efficiently to the transmission of the infection.

Now all these facts are extremely disagreeable both to hear about and to tell, and they can only be infinitely distressing to the victims of tuberculosis and to their friends and associates; but all the same they are facts, stubborn, abiding, and significant. The sooner we recognize the truth that every consumptive person may, if proper precautions are not taken, be an actual and active source of infection, not only to those who immediately come in contact with him, but to those who, either where he is, or where he has been, are forced to breathe dustladen air, the better will it be for all concerned.

Now of course no intelligent person would infer from this statement of facts regard- 
ing the sources of infection with tubercle bacilli through the air, that everybody who goes upon the street or enters a hospital or a theatre is going, or is even liable, to acquire tuberculosis. For, in the first place, the infecting material, even under the worst conditions, is enormously diluted by the circulating air, so that the individual chances of coming in contact with the dangerous material are slight. In the second place, the average healthy individual is not predisposed to the disease at all, and could be affected only under especially favorable conditions. Third, the amount of infecting material is apt, in transmission by the air, to be small, and this is a condition which diminishes the chances of danger from such exposure. Finally, every individual has in his respiratory tubes an arrangement of tiny cells whose free surfaces are covered with little hair-like processes called cilia. These are ceaselessly waving to and fro, and tend to sweep up and away from the lungs foreign particles which may be breathed in with the air. But notwithstanding all these conditions which serve to guard the exposed indi- 
vidual against the disease-producing bacteria, it still remains true that no man can acquire tuberculosis without getting into his body this particular bacillus from some infected individual or animal.

The Bacillus tuberculosis can be cultivated artificially in the laboratory on potatoes or other solid media, provided the surfaces are kept always moist and the temperature kept approximately at that of the human body. It does not grow in nature outside of the human or animal body, but it may remain alive for a long time, even in the thoroughly dry condition, and ready to grow again when it gets into the body under favorable conditions.

The conclusions which almost thrust themselves upon us from what we have thus learned about tuberculosis are very plain. Tubercular cattle ought to be killed at once and their carcases burned or otherwise rendered innocuous just as soon as the disease is discovered, and never allowed to get into the markets. Pecuniary losses which individuals might thus suffer are not worthy of a moment's consideration as weighing against such obvi- 
ously necessary preventive measures. These ends ought to be secured first by a more rigid inspection of cattle and of meat on the part of authorized persons, and second by the enactment of such laws as would secure for persons who knowingly sell tuberculous meat or milk for food such penalties as they would incur from any other form of purposed or careless poisoning of their fellow-men.

It would be very difficult to stop by any sort of legal enactment the spread of the tubercle bacilli by means of the air from man to man. But a thorough acquaintance of all persons with the fact that a consumptive patient may be a source of actual danger to all about him, unless the proper precautions are adopted, would do much to lessen the evil.

Steamship and railroad companies should be obliged to furnish separate accommodations for persons thus affected, so that no well person should ever be forced in the exigencies of travel to expose himself to the liability of infection.

Such regulations and discriminations as are here suggested would of course often be 
extremely annoying to the victims of the disease and their friends as well as to all immediately concerned. But some such understanding must be come to, unless people are to go on needlessly dying from this most important disease.

The best way of disposing of the sputum of consumptive persons, which, if allowed to dry, may, as we have seen, become the source of active danger to himself as well as to others, is by burning.

It may be received into smali cheap wooden or pasteboard boxes, which are now made and sold very cheaply by the druggists, and which at frequent intervals, together with their contents, should be burned in the stove, furnace, or fireplace. When handkerchiefs or cloths are used to receive the material coughed up, these should be either burned as early as possible, or soaked for several hours in a five per cent. solution of carbolic acid and then boiled and washed. But the use of handkerchiefs and cloths is to be avoided for this purpose as much as possible, because they afford most favorable conditions for the drying and distribu. tion of the infectious material. 
But while we are thus led by the knowledge which has been gained of the tubercle bacillus to a more precise notion as to what should be done to prevent the spread of the disease, what has the accumulated lore to offer of hope or comfort to those already stricken. In the first place, the physician can now say positively by finding the bacilli in the material discharged from the lungs, in many cases even in very early stages, that the lung is diseased: and we now know that consumption is by no means a hopeless disease, especially if it be detected in its early stages. We know that the cells of the body, if they are in a properly active and vigorous condition, have a tendency to destroy the germs. And in a great many cases the wise physician may, by recommending changes of climate, improved conditions of hygiene, proper exercise and food, as well as by the giving of sustaining and strengthening medicines, hold out to his patient a good hope of ultimate recovery or of prolonged and comfortable life.

We battle to-day at any rate with a known and comprehensible foe, and no longer grope 
in the dark after a mysterious and unknown enemy. The hope of the enlightened physician looks out towards a time when we may have learned some direct and efficient means of destroying the invading germs in the body, but, in the meantime, by aiding the body's inherent means of cure, he feels himself no longer helpless, and is grateful for so much aid as scientific research, as yet, has furnished him in dealing with this dread disease. 


\section{CHAPTER VIII.}

BACTERIA AND TYPHOID FEVER.

TYPHOID fever is one of the serious and

1 common diseases, occurring among all classes of people, which is definitely known to be caused by bacteria. The germs causing this disease are little rods or bacilli considerably larger than those which cause tuberculosis. There are several forms of low fever, and some other diseases due to various causes, which considerably resemble typhoid fever, and are not infrequently mistaken for it. But genuine typhoid fever is caused by this particular. germ, and no other, and is never caused in any other way.

This typhoid bacillus is not known to grow outside the body, to any considerable extent at least, except when artificially cultivated by the biologist for purposes of study. But it may remain alive for a good while outside the body in water $\mathrm{Or}^{*}$ under other conditions. 
The typhoid germ, in the large majority of cases, attacks the body through the intestinal canal. When it gets into the intestines, if in sufficient quantity and the conditions are favorable, it multiplies, and enormous numbers of the germs are thus produced. Some of these gain access to certain of the other internal organs, but most of them either complete their existence in the intestinal canal, or are cast out in the living condition with the diar rhœal discharges which so $\_$constantly accompany this disease.

It seems most probable, from what we know at present about the action of the typhoid bacilli in this disease, that, as they grow and multiply in the bowels, they produce a soluble poison-ptomaine,-which is absorbed, just as some kinds of food might be, and carried to various parts of the body, producing effects which we recognize as symptoms of the disease. The bacteria themselves remain, as it would seem, for the most part, in the intestinal canal, to pass off in the discharges.

The great and important source of infection -the means by which the disease is usually 
spread-is these discharges from the bowels, containing the living, virulent typhoid bacilli.

Here, we have an essentially similar condition of affairs to that in tuberculosis, namely, bacteria of a particular species causing a disease which, without them, could not or does not, so far as we know, exist, and after inducing the disease in an individual, being discharged alive and virulent from the body. Here, as in tuberculosis, although the mode of infection is somewhat different, if all the discharges from persons suffering from the disease could be immediately destroyed by carbolic acid or corrosive sublimate, all danger of infection, so far as we know, would be removed. Typhoid fever is thus a preventable disease.

So far as we know, typhoid fever affects man alone, and he alone forms the source of infection. But, unfortunately, the bacteria are not generally destroyed, and the house-mates of the patient, or those who use the same water supply, or are dependent upon the same food sources, or subject to a connecting and defective sewage system, now and then are liable, through food, or water, or air, to take into the 
intestinal canal some of the tiny germs, not larger than the motes in the sunbeam, but bearing in them the seeds of disease, or even death.

Altogether the probabilities are that in the majority of cases the typhoid-fever germs are most frequently carried and consumed in water which has in some way been polluted by human waste containing the typhoid germ.

It seems quite incredible, when put down in black and white on paper, that responsible and sane persons of ordinary intelligence, knowing that typhoid fever is caused by a living germ, knowing that this is thrown off from the body in the living condition and without being destroyed, is allowed to run through the sewer pipes into the nearest stream or lake, should for an instant consent to have the water of this stream or lake taken from within a short distance of the sewer opening, and often in line of direct current, and distributed in their houses unpurified, and used upon their tables. And yet it would be but the telling of old stories for the writer to cite case after case in which this offence against 
common decency, to say nothing of good taste, is practised under conditions much more flagrant than these. And then Providence or Fate is shouldered with the responsibility when the careless or ignorant persons themselves, or the innocent victims of their criminal neglect, are stricken with typhoid fever.

There is little doubt that the typhoid-fever bacilli sometimes enter houses from sewer pipes containing them, owing to defective traps or leaks in the pipes. Sewer gas is in itself a very bad thing to have pouring into houses, and is capable of inducing a great variety of disturbances of health, some of which are very serious indeed, but sewer gas alone cannot induce typhoid fever. For that the bacillus itself must be present. It is probable that when the traps are allowed to get dry, as no doubt often happens in shut-up city houses during the summer, currents of sewer gas sweeping up through the pipes, on whose walls the typhoid bacilli have collected, may dislodge these, if the sides of the pipes are dry, and carry the germs as floating dust into the rooms, where they may settle, and 
finally, sooner or later, gain access to the food or drink of the inmates. This mode of conveyance of the germ of typhoid fever has not yet been proven, but, as a reasonable hypothesis, is closely in accord with what we know but too well of the outbreaks of typhoid fever which so often occur on the return of households in the autumn to their city homes.

It has been abundantly proven by careful experiments that the typhoid bacillus can remain alive for long periods when frozen solidly in a block of ice. The disease-producing bacteria which may be conveyed in ice in impure water to the body will be considered in a subsequent chapter. 


\section{CHAPTER IX.}

THE RELATIONS OF BACTERIA TO ASIATIC CHOLERA.

\section{U ISTORY records many tragic stories of 11 sudden outbreaks of fatal disease which} spreading like wildfire among the people have brought untold miseries and countless deaths.

In early times these frightful whirlwinds of disease were looked upon as penal visitations of the Supreme Powers, and in the utter panic which they so often induced little was done in the way of studying their nature or staying their progress.

Among the more important of these tragic epidemics which have been experienced and carefully observed since science has withdrawn the veil of superstition from them, stands Asiatic cholera.

In some parts of the world this disease is constantly present and claims each year a vary- 
ing number of victims. But Europe and America are in general free from it, save that now and then coming from its home in the far East it sweeps along the seaboard or over the country, bringing in a greater or less degree the oldtime panic and misery and death in its train. Occasionally it finds lodgment upon our own shores and has penetrated into the interior.

Now up to within a few years we have not known what the cause of this disease really was. It seemed to be something which could be brought in ships and wrapped up in clothing, and was evidently communicable from man to man. Such measures of stopping the spread of the disease by isolating the sick, and such general regulation of the diet and habits as seemed from experience best adapted to protect the well, were formulated and practised. But the utter lack of knowledge as to the exact nature of the contagion frequently rendered futile the one and uncertain the others.

To-day we know that Asiatic cholera is caused by a little curved bacillus, which on getting into the intestinal canal of human beings multiplies with such rapidity that 
within a few days or hours the body may be overwhelmed with the poisonous material which it eliminates as it grows. We know that in certain stages of the disease the living germs are discharged from the body in vast numbers, and that if moisture be present they may remain alive outside of the body for long periods and may even multiply. They can thus remain alive for some time in water and on the moist surfaces of vegetables and fruits and clothing.

There is no good reason for believing that any other germ or organism than this particular curved bacillus ever induces Asiatic cholera, or that the disease is ever caused by any thing else. The only known way in which the infection is conveyed from man to man is by the taking into the intestinal canal, either by water or food or in some other way, some of the cholera bacilli which have come directly or indirectly from some human victim of the disease.

The germs may remain alive for a long time if kept moist, and so the disease may be conveyed for long distances in bundles of infected clothing. A few hours of thorough drying or 
steaming, or the application of suitable disinfectants, such as strong carbolic acid or corrosive sublimate, readily secures total destruction of the life of the germs.

In Asiatic cholera, as in all of the other bacterial diseases which we have thus far studied, predisposition of the individual is an important factor in the acquirement of the disease. This simply means that there are certain conditions of the body cells which render them less able to resist the incursions of foreign organisms like the bacteria, or which furnish conditions favorable to their growth and proliferation.

We have seen that in tuberculosis this predisposition to the disease, whatever its exact nature is, may be in marked degree hereditary. In Asiatic cholera a disordered condition of the digestion appears to favor the occurrence of an attack of the disease. In typhoid fever, analogous predisposing factors seem to determine that when exposed to the same risk of infection one individual may be attacked with the disease and another not. But alike in all these forms of bacterial disease the particular 
species of bacteria belonging to each must be present, predisposition or no predisposition, or the disease cannot occur.

Typhoid fever and cholera are often called filth diseases, and to bad food, foul air, sewer gas, and overcrowding their occurrence has often been attributed. This is in a sense true, since these adverse conditions are apt to induce a state of the body which renders it less resistent than it should naturally be to various deleterious agencies; but no imaginable degree of unsanitary conditions could ever induce tuberculosis, or typhoid fever, or Asiatic cholera without the presence of the particular germ which causes each. None of these diseases can spring up among any class or condition of people without the introduction of the germ from outside.

The recently acquired knowledge of the cause of Asiatic cholera has thus far aided but little in the treatment of persons already its victims. On the other hand, knowing definitely, as we now do, what causes the disease, how and under what conditions it spreads, and what will destroy the germs, we are to-day in 
a condition, wherever sanitary and proper quarantine regulations are efficiently carried out, to largely prevent the access of the disease to our country, to stay the progress of an epidemic at its very outset, and to promptly allay the panic which the advent of a mysterious and deadly scourge is so prone to incite 


\section{CHAPTER X.}

THE RELATION OF BACTERIA TO DIPHTHERIA, PNEUMONIA， SCARLET-FEVER， ETC.

THERE are several diseases besides those

1 which we have considered in some detail which are proven to be caused by the entrance of bacteria into the body. There is a still larger number which we believe, and with the very best of reasons, to be caused by bacteria, but from which the germs have not yet been isolated and carefully studied so that we can speak positively about them.

\section{Diphtheria.}

Diphtheria is one of the most dreaded of the diseases, especially in childhood, which are known to be caused by bacteria. We are not yet quite certain whether it is always caused by one form of germs, or whether in the different outbreaks or in different regions sometimes 
one and sometimes another species induces the disease.

It has been shown that diphtheria, as it occurs in children's asylums in New York, may be caused by a streptococcus, which, when it gets into the mucous membranes of the air passages, especially if these are already in an inflamed condition, can produce those local changes which are so well known to accompany this serious disease.

It has been furthermore shown that these streptococci may remain alive for long periods, when thoroughly dried, as in the dust, and it has been found in the living and virulent condition floating in the dust of the air of rooms in which children suffering from diphtheria were confined. It has been found in the mouths of children who had been exposed to the disease, and very soon after some of these children suffered from serious and fatal attacks of diphtheria. This bacterium has been shown to be readily killed by moderately strong solutions of carbolic acid and corrosive sublimate.

It is very well known that if the membranes which are so apt to stop up the air passages in 
diphtheria, when in the fresh condition, come in contact with the mouths or air passages of healthy persons, they may set up the disease. This is because the material composing the membranes may contain large numbers of the living, virulent germs. It is furthermore known that the poison of diphtheria may linger for long periods in rooms where the disease has occurred, and may be conveyed on the clothing of persons who have come in contact with the sick.

Now in this, as in the other bacterial diseases which we have studied, if all the material which is cast off and discharged from the body were at once received into strong disinfecting solutions or burned, so that the germs might be killed, the disease would have little tendency to spread. But if, as is too often the case, the discharged particles are allowed to collect on handkerchiefs, or bedding, or clothing, or on the floors, they dry and finally become ground up and mingle with the dust, and as the germs are not killed to any great extent by the drying, when the dust is inhaled it may, if the individual be in a favorable condition for its development, grow and induce the disease. 
It is not unlikely that the dried diphtheria germ may, from faulty plumbing or dry traps in the pipes, be blown into rooms along with the sewer gas, and that thus the disease is sometimes communicated without direct contact with an infected person.

\section{Pneumonia.}

Pneumonia, in its more common phases, is another of the diseases which we believe to be caused by bacteria. The germ which produces the trouble has been many times separated and carefully studied. It is called the Pneumococcus.

So frequently does this disease follow exposure to cold or wet, and so often does it begin with symptoms which resemble those of an ordinary cold, that it was long believed to be, and still is popularly regarded, as usually caused by these exposures. But most of those who have carefully studied the disease by the use of the modern scientific methods, of research are disposed to believe that the, exposure to cold and wet and other ? wes well-denced conditions which were formerly ragaraed, as 
actual causes, while exceedingly important, are yet simply predisposing factors. They believe that the reason why pneumonia is so frequently associatcd with these conditions is that they in some way fit the lungs to be a good growing place for the germs if at the favorable moment they gain access to them through the mouth.

We do not know much about the bacteria which thus appear to cause pneumonia, so far as their lurking places outside of the body are concerned. But they are not infrequently found in the mouths of healthy persons, and are most likely distributed through the air with the dust.

The pneumonia which so frequently comes on as a serious complication of diphtheria has been shown to be caused by the germs which cause the diphtheria itself getting down into the lungs and producing their poisonous effects there.

Scarlet-Fever, Measles, Yellow-Fever, etc.

There is a great deal in the nature and mode of comminication of scarlet-fever, measles, 
whooping-cough, and small-pox which indicates that they too are bacterial diseases; but the specific organisms causing them have not yet been identified. So that in attempting to guard against their spread we are at present obliged to make what use we can of the facts which we know about the proven bacterial diseases and the experience which has been accumulated by physicians who so long and faithfully have studied them at the bedside. Against small-pox, however, we have a most efficient safeguard in vaccination, although we do not yet know the reason for the marvellous protective effects of the procedure.

\section{Yellow-Fever.}

Yellow-fever is a disease of the utmost importance in some parts of our country, about the cause of which we are almost entirely in the dark. Our knowledge of it is largely confined to the characters of the disease as it is seen at the bedside, and to the general conditions under which it is liable to occur and spread. In many respects it resembles the known bacterial diseases, in others it differs 
considerably from them. The attempts which have thus far been made to find bacteria to which it seems likely that it may owe its origin have not been successful, although several claims in this direction have been widely published.

\section{Malaria.}

Malaria, in its protean phases, has been thought by many to be caused by bacteria, but the reliable observations thus far made do not appear to support this view. There are peculiar minute organisms very constantly found in the blood in certain stages of malarial poisoning which may ultimately prove to be the cause of the attacks. But as this is not yet definitely settled, and as at any rate the suspected organisms are not bacteria, but belong in that lowly group of animals called protozoa, we need not consider them further here. 


\section{CHAPTER XI.}

IMPURE FOOD AND AIR AS SOURCES OF BAC. TERIAL INFECTION.

$\Lambda \mathrm{S}$ we glance back over the ground which we have traversed together, we see that the most common bacterial diseases which in this country we are apt to come in contact with, so far as they are definitely known to us, are tuberculosis, typhoid fever, diphtheria, pneumonia, and the wound diseases or blood poisoning.

We have seen that in most of these diseases the poison is liable to spread from one individual to another, because it is not destroyed by disinfectants, or in some other way, as soon as possible after it is discharged from the diseased person.

We have seen that the most common ways in which the virulent bacteria are spread are by the air we breathe, the food we eat, and 
the water we drink. If any of these necessities of life contain in them the living germs of these diseases, there is a liability of the infection of healthy or predisposed individuals.

The liability to acquire these diseases is always increased in direct proportion to the crowding together of the sick and the well under unsanitary conditions in large communities. This is not because filth and dirt are in themselves infectious, but because pathogenic bacteria are liable to become mingled with the rest. In other words, there is a simply filthy filth, and there is a pathogenic filth, and the two are very apt to go together.

No gas, however foul, no accumulation of dirt, no degree of malnutrition or misery or overcrowding can induce an infectious disease. It is always and everywhere some particular form of disease-producing germ which causes the trouble. The other influences bear largely upon the chances of incurring the disease, and often determine the severity of its course or its fatal ending, but they alone cannot cause it.

In considering what ought to be and what can be done to prevent the spread of the bac- 
terial diseases, it is evident at once that there are two distinct classes of preventive measures: first, those which must be arranged and enforced by the public authorities, such as Health Boards and their officers; and second, those which depend upon the intelligence, knowledge, and faithfulness of private individuals. It does not lie within the scope of this little book to consider, except incidentally, the measures which should be taken by the authorities on the large scale, to ward off epidemics or to secure proper sanitary conditions among the people.

It is not, in fact, the great and sweeping epidemics, dramatic and frightful as they are, which carry off prematurely the largest number of people; but it is the bacterial diseases which we have constantly with us, and to which we have become so accustomed that we do not usually realize their vast importance, and against which systematic and persistent crusades on the part of the health authorities are only occasionally and fitfully undertaken. Among the bacterial diseases which are well understood, the most important, in some re- 
spects, in this country are tuberculosis, typhoid fever, and diphtheria.

The danger of infection with disease-producing bacteria which we may encounter in the ordinary paths of life lurk, as we have seen, for the most part, either in food, or air, or water. Let us now look at these sources of danger a little more closely.

\section{Impure Food as a Source of Bacterial Infection.}

We have seen that the meat of tubercular cattle and the milk of tubercular cows, and the same is true of tubercular fowls, may contain the living tubercle bacilli, and that if the meat be not thoroughly cooked and the milk not thoroughly boiled, these germs may get into the intestinal canal, and cause disease. The remedy here lies in part in the hands of the health officers, or, when their efforts fail, in the hands of the consumer himself. A much more rigid inspection of cattle, with full authority to destroy all infected herds, should be at once established. It should be thoroughly understood by every householder, that if this be not done, uncooked meat, of 
whatever kind, should be altogether avoided; and the same should apply to milk. The boiling of milk for from three quarters of an hour to an hour suffices to kill the germs of tuberculosis.

Scarlet-fever and diphtheria may also, as has been abundantly proven, be transmitted by milk which has in any way been exposed to the infection; and hence the thorough boiling of milk, in cities where the source of the supply is not definitely known, would be a wise precautionary measure.

Milk is such an excellent food medium for the greatest variety of bacteria of nearly all species, that although bacteria-free when it comes from the cow, it may, before it reaches the consumer, contain several millions of living germs to one teaspoonful. Now it has been found that milk which contains a great many bacteria, although these may not be of a kind which ordinarily produce any well defined disease, may in young children produce digestive disturbances and diarrhœea, which is often of a very serious character. Milk from the ordinary unknown sources of supply ought 
therefore to be thoroughly boiled before it is fed to infants and young children, and very simple and inexpensive forms of apparatus for this purpose have been devised and can be recommended by any well informed physician.

As the germs of various diseases may be floating in the air, especially in densely populated regions, all fruits, vegetables, and salads ought to be thoroughly washed before they are eaten, unle'ss they are to be cooked. The exposure of such articles of food on the sidewalks in cities, as is so often done, is a most reprehensible practice, and this alone should be enough to decide the householder to dispense with the supplies of any dealer who persists in it.

There is no doubt that the germs of typhoid fever, and, when it is prevalent, those of Asiatic cholera, are conveyed from one to another by means of food on which in some way the germs from the discharges of sick persons have lodged. This is of course most apt to occur among the poorer classes in large towns whose market-stalls are the gutters, and whose living-rooms, alike for sick and well, may 
serve at once as kitchen, dining-room, garbage reservoirs, and bedchambers. But among those more fortunately circumstanced, the conveyance of the diphtheria, and probably of typhoid-fever germs, on uncleansed spoons, dishes, etc., is of no infrequent occurrence.

The Air as a Source of Bacterial Infection.

We have seen that the only way the air which we breathe can be actually infectious, that is, can be the means of transmitting a bacterial disease, is, under ordinary conditions, by carrying as dust the dried but living. diseaseproducing germs from some infected individual or animal along with other and less harmful dust. Thus it is that our recently acquired knowledge of bacteria and other minute organisms has brought a new significance into the problems of ventilation. Foul air we still know to be bad and capable of inducing serious forms of disease, but the specific and most significant elements of positive danger reside in the floating dust.

The possibility of taking the bacteria of tuberculosis and diphtheria into the mouth 
and lungs with the air out-of-doors, especially in large cities, is, as we have already seen,imminent and widespread, but ordinarily the dilution of the dangerous elements is so great as to reduce greatly the chances of evil effects from swal. lowing or inhaling them. But still, in large towns, whose streets are not faithfully cared for, the probability of being obliged to pass through clouds of dust whenever one goes upon the streets, especially in the windy seasons, is very unpleasantly suggestive of danger, and more than suggestive of filth.

In New York, even in districts where the streets are measurably frequently attended to, the insufficient watering of the pavements before the street-sweepers pass, the long periods which often elapse before the dirt heaps are carted off, and the reckless way in which the dirt is shovelled into the carts, are all evidences of carelessness which greatly increases the risk of street infection, and abuses which ought to be at once corrected.

But, after all, it is in living-rooms and in places of assembly that we must look for the most frequent sources of danger. While, as 
we have seen above, there is a certain hereditary predisposition to tuberculosis which is resident in the body cells themselves and of the exact nature of which we are quite ignorant, there is little doubt that one of the most important reasons why tuberculosis is apt to run in families is that children and relatives of consumptives are more liable than others to come in direct contact with the disease-producing germs, which have been thrown off from the bodies of their house-mates under conditions which permit of their drying and inhalation as dust.

Theatres and churches, especially the former, are apt, as is well known, to be altogether inadequately ventilated. The headache and malaise which are so prone to follow a visit to many of our theatres, are evidences of the bad air which we are usually forced to breathe there; but the more subtle dangers here, as elsewhere, lurk in the dust which equally with the bad air is forced upon us.

No adequate means exist in most theatres for ridding the air of the dust. The best of them indeed are swept and "dusted" system- 
atically and the larger particles of dirt collected and removed; but the floating dust is simply stirred up, and after settling is stirred up again by the so called duster, and so partially removed from the seats, but it settles again on the floors, to be again set in motion by the entering and retiring audience. It would be safe to say that the only systematic mode of removal of the floating dust from many of our popular theatres and churches is by its lodgment in the throats and lungs or on the clothing of the people who visit them.

Some of the newer theatres are furnished with improved and sufficient ventilating apparatus, but some of them are not, and while we admire the chaste gilding and sumptuous upholstery of the interior, and complacently reflect that at length the law has forced builders of places of amusement to afford a measurable degree of security against being burned alive, that element of danger in large assemblies, more important and more subtle than all the rest put together, namely, inadequate ventilation, is rarely commented upon or thought about. There ought to be definite 
regulations for all public assembly-rooms, which should insure the forcing of a proper amount of fresh air through them, which would not only carry off foul air, but much of the floating and possibly infectious dust with it.

In dwelling-houses, the problem of ventilation is in many respects simpler than in large assembly-rooms, because to a certain extent the householder is aware of the possibilities of dust infection, from the condition of health of the inmates, and can act accordingly. But even here, under ordinary conditions, there seems to be, from what we have learned about the bacteria, more reasons than we have before appreciated for securing adequate ventilation-such ventilation as shall carry off not only the used-up air but the floating dust.

The ordinary practice of occasionally stirring up the settled dust with a feather-duster should give place to the use of moist cloths or dry cloths frequently shaken out-of-doors, so that the dust may be removed and not simply redistributed. This becomes the more important if any inmate of the house is suffering from one of the bacterial diseases. 
In the interests of health the fitting of houses with simpler furniture or less heavy hangings and fixed carpets is greatly to be desired.

The regulation of the sick-room, and its communication with the rest of the house, is a matter on which the advice of the physician should be sought. First and foremost should stand the systematic and careful destruction of the infectious material in all discharges of whatever sort from diseased persons, by burning or by the proper disinfecting solutions such as five per cent. carbolic acid. In this solution the discharges should be allowed to soak for several hours before they are thrown into the sewer or otherwise disposed of. As to the cleansing of rooms after their occupancy by persons who have suffered from bacterial diseases, directions should be obtained from the physician or from the health authorities.

The danger of infection with the germ of tuberculosis through the air is very widespread, because consumptive persons are often for long periods not confined to their houses, or rooms, or beds, but may be more or less active centres of infection by mingling with the well in all the 
ordinary walks of life. We have seen already by what comparatively simple means a large part of the danger of the spread of tuberculosis and diphtheria might be prevented. The risk of dust infection from diph theria, and probably from other somewhat similar diseases, such as measles and scarlet-fever, is more apt to be limited to rooms or houses where the disease has occurred, because the victims of these diseases are usually sick enough to be confined to the house or bed. But there are, as all physicians know, frequently enough cases of these diseases in which the patients go about among their fellows throughout the whole course of the illness, or at least for some time after it is fully established.

The possibility of dust infection with any of the diseases which we have been considering, emphasizes the importance of breathing through the nose and keeping the mouth shut except when it is necessary to have it open. 


\section{CHAPTER XII.}

IMPURE WATER AND ICE AS A SOURCE OF BACTERIAL DISEASE.

\section{Impure Water.}

\E have seen in another part of this book that natural surface waters always contain considerable numbers of living bacteria of various kinds, which are growing and proliferating there, and no doubt actually purifying the water in a certain way by feeding upon and removing from it organic material which has collected or been dissolved. Now these bacteria in moderate numbers, under ordinary conditions, are not at all harmful to the consumer of the water for drinking or culinary purposes.

But, on the other hand, if the water becomes stagnant and the ordinarily harmless bacteria collect in very large numbers, it has been abundantly shown by most bitter 
experience that the use of the water may give rise to serious or even fatal acute disorders of the digestive system. Cholera morbus and the so-called winter cholera are apparently sometimes caused in this way. Young children are especially susceptible to the bad influences of such water, and the boiling of it, or the change of supply, has repeatedly been found sufficient to stop attacks of cholera infantum or the summer diarrhoea of young children.

On the whole, however, the bacteria which water naturally contains as it is found in lakes, running streams, and good springs are quite harmless, unless they are allowed by stagnation to accumulate to a very considerable degree. We do not yet definitely know to what extent the ordinary harmless bacteria might be allowed to accumulate in drinkingwater before it would become harmful. But the limit is usually somewhat arbitrarily placed at present at from three hundred to five hundred to the teaspoonful.

The frequent real and serious dangers from impure drinking-water do not lie in the bacte- 
ria which naturally occur there at all, but in those which get into it from outside, through pollution by the waste from animals and human beings, and especially from human beings who are the victims of some bacterial disease.

Polluted water may convey the bacteria which cause Asiatic cholera, and the same is true for diphtheria or the wound diseases, and doubtless many others, but the spread of these latter diseases in this way is no doubt quite infrequent.

It is typhoid fever, whose germs, of all those which cause disease, are, so far as we now know, most apt to be spread by polluted water. The discharges from persons ill of typhoid fever, thrown without disinfection into the vaults of country or village out-houses, -which, in an appalling number of cases, are in direct communication, through underground channels, with the wells, or with springs from which the farmer supplies the family or guests, - may pass, with but a very moderate dilution, into the digestive tracts of the unsuspecting victim. It is ignorance, not Providence, which, 
under these conditions, determines an epidemic of typhoid fever.

The water supplies of large towns come, for the most part, either from large rivers, or lakes, or artificial reservoirs along the course of smaller streams, or from artificial wells, which, piercing the upper strata, gain access to the deep underlying collections. Now in the surface water supplies, as from rivers or from lakes, man is his own worst enemy, because the most serious dangers from impure waters arise from its contamination with human waste.

Many great water supplies, which, under ordinary conditions are good, are constantly liable to become sources of danger, because the sewage from dwellings is discharged, if not into them, still, so near to them that it may now and then enter, being washed in by rains or in some other way. This, under ordinary conditions, may, if the sewage be largely diluted in the reservoirs or streams, be simply disgusting and filthy, though not positively dangerous. But if, as is at any time liable to happen, typhoid-fever discharges get into the waste-pipes and so into the water, the 
danger of the spread of this disease becomes of great importance.

The great water supply of the city of New York, the Croton, is of this character. The water comes from a large territory known as the Croton water-shed, and is naturally a very good water supply indeed; but along the streams and reservoirs which collect the water are numerous villages and scattered dwellinghouses. While some attempt is made to keep the banks of the water-ways free from sources of sewage and waste contamination, as they are largely private property this is not adequately done, and at any time an epidemic of typhoid fever in houses or villages along the Croton streams and lakes would be liable to cause a dangerous contamination of our city supply.

There are two ways in which this positive danger can be obviated. One is by the purchase, by the State, of a strip of land along all the shores of the Croton water system, and the removal to a safe distance of all possible sources of contamination.

Another means of security, which, perhaps, 
in the long run would be the most efficient and most thoroughly under control of the authorities, would be the construction of large filter-beds, or filtering apparatus, by means of which the water mignt be freed from all dangerous contaminations under all conditions. It will thus be seen that while the Croton water is not at present a source of actual danyer it may at any moment become so, unless some efficient means be taken to protect its sources, or purify it before distribution.

Conditions similar to that of the Croton are very common in the city water supplies everywhere, in this, as in other countries. And the more rapidly are the regions from which the water is derived becoming populated, the more serious does the danger grow.

Another great source of water supply for large cities and towns is the rivers on whose banks they are built. The water is usually taken ar a point some distance above the town, so as to avoid the sewage of the town itself, which, as a rule, is allowed to escape directly into it. But in almost all cases, in thickly settled countries, there are other towns 
on these streams above the points at which the water is taken, polluting it with their sewage. Now so prevalent is typhoid fever all over the civilized world that the sewage of every large town is liable to contain greater or less numbers of living typhoid bacilli.

The city of Albany, N. Y., which takes its drinking-water from the Hudson River a short distance above the town, just after it has received the sewage of Troy and that of several smaller towns on the banks of both the Hudson and the Mohawk above, is an example of a city which relies upon a water supply always both filthy and dangerous.

Philadelphia is another great city whose water supply from the Schuylkill River is of the most dangerous and disgusting character, from its large admixture of sewage and human waste. The typhoid-fever statistics of Philadelphia are abundant witnesses to the almost incredible apathy or carelessness of its authorities.

In older countries where the sanitary dangers which always grow with the increase and massing together of the people have been 
longer observed and more definitely recognized than in our own, legal enactments have been long in force to prevent the pollution of streams which might be sources of water supply of towns. But still large cities like London and Berlin have found it necessary to further protect themselves against disease-producing organisms and against filth, by the maintenance of filtering systems on the large scale, by which the dangerous elements of a contaminated water may be largely or entirely removed.

We should not forget that contaminated water always tends to purify itself in certain ways when exposed to the air in large volumes, as in lakes or running streams. Nor should we lose sight of the fact that a moderate amount of sewage, when poured into a large volume of water, becomes so considerably diluted, that its dangerous elements are much less numerous in any given glass or volume of water than in sewage itself. But such considerations can afford but little real consolation to those who find themselves forced to drink sewage, even though it be very largely 
diluted. The sewage may contain one hundred thousand typhoid germs to one teacupful, while the diluted mixture has in it not more than one to the same volume. But it should never be forgotten that the one germ is capable of multiplying in the human body to an enormous extent, and for this reason, in the living bacterial poison dilution is of much less significance than in ordinary poisons which are not alive and self-propagating.

The fact is, that in view of all that we have seen of the nature of bacteria and their disease-producing powers, sewage-polluted water from wells, or springs, or rivers, or lakes, ought not to be used for drinking and culinary purposes without some system of purification which is demonstrably efficient.

The new methods of bacterial analysis of water, which have been described in the earlier pages of this book, now enable us to tell with a great deal of certainty, sometimes with and sometimes without a chemical analysis, whether or not a given water has actually been polluted with sewage, or human or animal waste, and whether the modes of purification to which it 
has been subjected, either naturally or artificially, have actually been efficacious in removing the living germs.

It is thus evident that upon the intelligence, knowledge, and fidelity, of the authorities largely rests the responsibility of pure water supplies for cities and towns, and the householder is to a large degree at the mercy of these officials, so far as his protection against the acquirement of bacterial disease, especially typhoid fever, is concerned. For it has been shown over and over again, by the most careful and elaborate experiments and examinations, that the small so-called faucet filters, and pretty much all the reservoir domestic filters, do not separate the bacteria from contaminated water in a reliable way. The water is often strained by them and so freed from its coarser floating particles, and then may appear quite clear and limpid, and some of the bacteria may be at first removed; but after a little while not only do these small filters let the invisible bacteria through their pores in large numbers, but they may actually afford breeding- and lurking-places for the living 
germs, - the disease-producing forms among the rest.

Filtration on the large scale in properly arranged systems appears to be the only reliable way of freeing contaminated water mechanically from its bacterial ingredients.

Thorough boiling of water for at least an hour will, however, kill the bacteria, and to this, in the last resort, the householder must have recourse when the water supply is justly suspected to be causing and fostering disease. This purification of water by boiling may be done by the householder himself, or, if he can afford it, he may supply himself with the distilled and aërated water which is now furnished in many towns.

But, after all, when the facts about the dangers of a polluted water supply become generally known, it ought not to be necessary for the householder to adopt any domestic precautions against water infection in towns or cities. If politics, or private or corporate greed, or general ignorance or apathy stand in the way of sanitary reform, the outlook for the water consumer is indeed not encouraging, 
but even these obstacles in the way of comfortable existence have been and may again be set aside.

Those who dwell in the country, and those who repair thither in the summer, should be very watchful of the water which comes from the ordinary wells. It is quite true that the water which soaks into the majority of wells in the country and in villages has been filtered, and more or less purified, as it passed through the soil and earth about the well. But in a great many cases the surface water runs directly into the well at the top. Washing is not infrequently done in the immediate vicinity of the well, and the waste and dirty water runs directly, or with but little filtration, back into the common receptacle. The vaults of outhouses, barn-yards, and pigstyes are often in close proximity to the well, on establishments which in circulars and newspapers figure as country health resorts. And this is by no means true alone of those which are inexpensive and primitive, but almost equally so of many of the more fashionable and popular resorts.

Every person who goes or sends his family 
into the country in the summer, should personally inspect the drinking-water supply and assure himself that it is good. This is actually of far greater importance than the size of the rooms, the price of board, or the diversity of amusements, or any other of the score of things about which one so scrupulously inquires before laying out the summer campaign.

Wells ought to be cemented water-tight for from eight to twelve feet below the surface. They should rise several inches above the level of the surface of the ground, which should be cemented and made to slope away in all directions from the opening, so that all drippings and surface water may be carried off to a distance of several feet before it soaks into the ground.

It should always be borne in mind that the water of ordinary wells is simply surface water, which has filtered down through the soil, and collected in the reservoir which the well excavation makes, and that in closely populated regions the soil, which originally may have been efficient as a filter, may finally bccome so 
filthy as not only no longer to cleanse the water, but to actually infect or contaminate it as it percolates through.

It is difficult to lay down rules by which the safety of country and village wells may be judged. But a very moderate acquaintance with sanitary principles will usually guide one to a just opinion. The argument which the enquirer is most apt to encounter favoring the salubrity of a country or village well, is that the owners' fathers and grandfathers drank water from the well all their lives, and they and their families lived to a good old age. But the fact is frequently lost sight of that the slops and sewage of this long-lived race have usually been accumulating in the soil about the house, as the years have sped, and as their towns and villages have grown the stables and hog-pens have neared the ancestral roof-tree. In short, that the sanitary conditions have entirely changed. The fact is, that wells, as they exist in most villages, and on many farms in this country, are an abomination and a perpetual menace to the health and lives of those who use them. 


\section{Impure Ice.}

The use of ice in preserving food and for drinking purposes has become a very important factor in modern life, and a means of incalculable benefit to all classes of people.

It was formerly believed that freezing destroyed in large measure the impurities of water, and within certain limits this is true. But it has been found, as the result of a long series of careful experiments by numerous investigators, that those important contaminating elements in polluted water, the bacteria, may resist for long periods the influences of cold. Good ice is so clear and beautiful that it is difficult to believe that it may harbor among its crystals large numbers of even such tiny bodies as the bacteria, but this is nevertheless quite true.

It has been found that the ice which is delivered in New York and in many other large cities actually contains large numbers of bacteria.

It has been further found that that most dreaded form of bacteria, the typhoid bacillus, may remain for long periods living and virulent in solid ice blocks. 
It follows directly from these simple but undeniable facts that the sources of our ice supply should be as carefully scrutinized in the interests of the public health, as should the sources of the water. But, unfortunately, under the influence of the old idea that water was thoroughly purified by freezing, it has become the general practice of many of the dealers to get their ice from almost any source, however unclean, which is near or accessible enough to the market to afford a profit.

One of the most flagrant examples of this bad practice is seen in the ice supply of New York City, which is in large part drawn from the sewage-polluted Hudson, and in many cases from the immediate vicinity of the sewer openings. Some of the ice which is supplied to New York is cut on moderately clean ponds or lakes, but the consumer is almost never certain that he is not getting Hudson-River sewer-ice, even when he may fancy he has a cleaner supply.

The fact is, ice should not be cut, at least when it is to be used for drinking purposes, from any source which would not be good if used for drinking unfrozen. This is certainly 
not the case with any of the Hudson-River ice, nor with much of that which comes from other sources.

The criterion of wholesome ice is of course the same for all regions of the country. The condition of affairs in New York is cited simply because it is an example of the extremely objectionable and dangerous practices which sensitive and refined people will indulge in from force of habit or from ignorance of the nature of their errors.

Many persons who are alive to the dirty and dangerous character of much of the New-York ice are looking eagerly either for a reform on the part of the ice dealers in the character of the places on which they cut their ice, or to the establishment of manufactories of artificial ice, which can be made from water purified by distillation. It seems at present, however, as if a spontaneous reform on the part of the ice harvesters were not to be looked for, and that this must be brought about either by legislative enactments or by a determined movement on the part of a large number of consumers.

The dumping of city garbage in vacant lots 
or in the water in the vicinity of towns is one of those barbaric practices which strangely enough still widely prevails in spite of the fact that both efficient and cheap apparatus for burning it are well known and employed by many of the more intelligent and cleanly communities. Thus the soil and the shores of streams and other bodies of water near towns are often polluted.

If sewage were everywhere systematically destroyed, instead of being permitted to run into and pollute the streams and lakes, which, from their size and situation, afford the natural water and ice supplies to towns in their vicinity, the problem, on which so much depends, of obtaining pure and safe water and ice would be much easier of solution. 


\section{CHAPTER XIII.}

THE END OF THE STORY OF THE BACTERIA.

C important is the subject of the causation $\bowtie$ of disease by these minute organisms, and so full is this field of the promise of practical and far-reaching benefit to man, that large numbers of scientific workers all over the civilized world are eagerly and patiently devoting their time and skill to the study of the disease-producing bacteria.

Great care and technical facility are required to carry on successfully this kind of investigation, and it is not at all surprising, since we have known how to study bacteria for but a short time, that we should as yet know but very little about many of the bacterial diseases, or that we should often be mistaken in our interpretations of what we do know.

There is the greatest temptation for workers in this field to magnify the importance of 
their own observations, or to claim as worldreforming discoveries the results of imperfect observation or misinterpreted facts.

The hope of the widespread prevention of misery and disease, even in the dim dawn of this new day, is so bright and cheering, and so full is the air of high-sounding promise of new and beneficent revelations, that one is reminded of the description by Lowell of the advent of a new phase of thought many years ago in New England. "The nameless eagle," he says, "of the tree Ygdrasil was about to sit at last, and wild-eyed enthusiasts rushed from all sides, each eager to thrust under the mystic bird that chalk egg from which the new and fairer creation was to be hatched in due time."

But in spite of mistakes and misinterpretations, in spite of the runaway enthusiasms which now and again lead the disciples of the new light to ignore the solid groundwork of experience which was founded in the old, we are daily gaining new facts and more commanding points of view, and the science of medicine has entered upon a new and brilliant epoch in its history. 
The mysterious veil which has for so long hung over some of the most widespread and terrible of human diseases, is gradually being drawn aside, and we now stand face to face with known and understood and no longer, for the most part, with mysterious and incomprehensible foes.

Ten years ago it would have seemed an idle tale had one said that he could cultivate at will in the laboratory the very living essence and causes of such diseases as consumption, typhoid fever, Asiatic cholera, diphtheria, and more of the uncanny brood, and could study and manipulate them as the gardener does his larger plants, and from the knowledge thus gained plan new and efficient means for treating and preventing the diseases which they cause. But all this is strictly true to-day, as we have seen in our review of man's invisible foes and the ravages which they can cause.

And so at last we are at the end of our story, so far as in such simple and hurried fashion it can be told to-day. It is a story which in parts is full of disquieting and unpleasant revelations, of facts which at first 
sight seem to make life under modern conditions less simple and attractive, and Nature, if we may so personify her, less man's friend. But after all there are few things more disquieting and unpleasant and unfriendly, to most people, than are disease and death, and these, sooner or later, will thrust themselves into the attention of everybody, be he cognizant or not of the varied disregard of nature's laws which for the most part they follow.

It should not be forgotten by those who are disposed to close their eyes to the disagreeable and malign influences which, in the guise of disease-producing bacteria so frequently surround them, that the rights of others, as well as their own mental ease, are at stake in this matter. One has the right, so far as he is himself concerned, to indulge in almost any dietetic uncleanliness, or disregard of sanitary rule with which he may elect to be satisfied; but he has no right to expose himself unnecessarily to the acquirement of such diseases as will render him a source of either positive or possible danger to his fellow men.

Among all the myriads of invisible agencies 
which are ceaselessly working for man's weal. we have discovered a few which are his deadly foes. We have seen that if one looks at the matter intelligently, the means of largely avoiding the evil effects of these dangerous earthneighbors of ours are comparatively simple and effective, if we do not hide our heads, or shirk, or waste our time in protestations and regrets.

There are many of the uncanny and disagreeable things of life from which it were better that most of us turned away our eyes. But the avoidance of some of those forms of illness, whose causes have been considered in this little book, is so closely dependent upon a general knowledge of their nature that the offence of unpleasant revelations may, it is hoped, be forgiven by the reader in view of the ultimate and universal good which these lines have been penned to foster. 


\section{INDEX.}

Abscess

Agar, as culture-medium for bacteria

Air, as source of bacterial infection . . . . . . 109

Albany, water supply of . . . . . . . . 122

Amoeba

Asiatic cholera

Bacilli

Bacillus of asiatic cliolera .

".

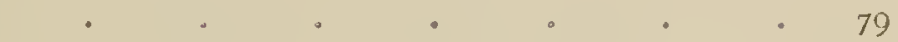

" " typhoid fever . . . . . . . . 84

" prodigiosus . . . . . . . . . 48

Bacteria, action of cold on . . . . . . . . 44

" always derived from other bacteria . . . . . 22

" antagonistic species of . . . . . . . 50

" chemical substances formed by . . . . . 21

" classification of . . . . . . . . 39

" color-forming . . . . . . 46, 47, 48

" consumption of, with food . . . . . 23

" cultivation of, in agar . . . . . . . 34

" " " "beeftea . . . . . 28

" " " " $"$ gelatin . . . . . 33

" " . " . . . . . . . . . . . 30

" development of, in hay infusion . . . . . 25

" disease-producing . . . . . . 53

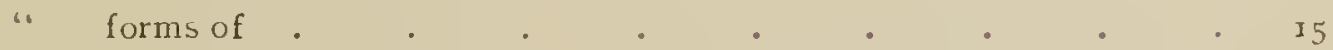

" " " colonies of . . . . . 37

" in air . . . . . . . . . . 109

" " . . . . . . . . . . 103

" "

" " $"$ relation to oxygen . . . . . . 44

" " water . . . . . . . . . . 116

" "wine- and beer-making . . . . 43

" mode of multiplication of . . . . . . $\quad$ I7 
Bacteria, movenents of

". nomenclature of . . . . .

" occurrence of . . . . . . . . . . 22

" of diphtheria . . . . . . . . . 96

" " measles . . . . . . . . . 100

" " " . . . . . . . . . . . 9 . 99 99

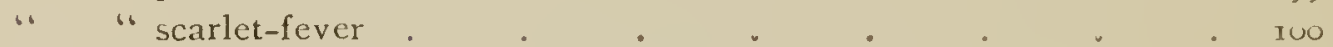

" "

" " tuberculosis . . . . . . . 70

" " "typhoid fever. . . . . . . . 84

" "yellow-fever. . . . . . . 101

" phosphorescent . . . . . . . 41

" place of, in scale of being . . . . . 15

“pyogenic . . . . . . . . 68

" rapidity of multiplication of . . . . . 17

“ relations to putrefaction . . . . . 20

" rôle of, in nature. . . . . . . . 20 20

" separation of species by fractional method . . . . 28

" " " " plate culture . . . . 35

" size of . . . . . . . . . .

" species of, mutually dependent . . . . . 50

" spores found in . . . . . . . . . . 19

" staining . . . . . . . . . 16

“ struggle for existence among . . . . . . 18

Bacterial diseases, prevention of . . . . . . . $79,86,104$

" poison, self-propagating .

Beef-tea, as culture-mecium for bacteria . . . . . 29

Berlin, water supply of . . . . . . . 123

Bleeding Host, miracle of . . . . . . . $4^{8}$

Blood cells . . . . . . . . . .

Blood poisoning . . . . . . . . 59

Bread, color-forming bacteria on . . . . . . 48

Burning of garbage . . . . . . . ${ }^{1} 32$

Carbolic acid . . . . . . . 81,97, 114

Cattle, tubercular . . . . . . . . 23, 106

Cells, as bacteria destroyers . . . . . . . . 66

" developed from the ovum . . . . . . . 9

" elementary nature of . . . . . . . 2

Childbed fever . . . . . . . . . . 62

Cholera, Asiatica . . . . . . . . . 90

" bacillus . . . . . . . . . gr

" morbus

Churches, bacteria in dust of

Consumption . $\quad . \quad$. . . . . 70 
Corrosive sublimate

Cremation of garbage

Croton water

Diphtheria, bacteria of

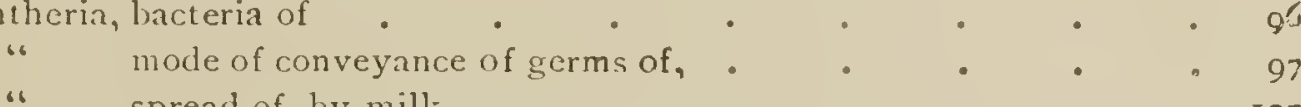

Dicease, nature of

spread of, by milk

" producing bacteria

Dust, as conveyer of infection of diphtheria

" as sonrce of infection with tuberculosis

" bacteria of wound diseases in

" germs of scarlet-fever, diphtheria, and measles in

" importance of, in ventilation

Frysipelas

Feather dusters

Fermentation

Filters, domestic

Filth diseases

Filtration

Food, impure, as source of bacterial discase

Fowl, tubercular

Furniture in houses.

Garbage, as a sonrce of sanitary danger .

Gelatin culture-media for bacteria

Germs

Holmes, Oliver Wendell

Ice, artificial

"bacteria in

" typhoid bacilli in

Inflammation, bacteria of .

Koch, Robert

Lencocytes

Living beings, characteristics of

London, water supply of .

Lowell, J. R.

Malaria

Measles

Micrococcus.

Milk and diphtheria

" scarlet-fever 
Milk and tuberculosis

" color-forming bacteria in

Moon, old plan for communicating with .

Muscle cells .

Nerves

New York, ice supply of

" " water supply of

Olynthus

Overcrowding and disease

Ovum

Pathogenic bacteria

Philadelphia, water supply of

Phosphorescent bacteria

Physiological division of labor in cells

Plate cultures of bacteria .

Pneumococcus

Pneumonia and diphtheria

$$
\text { " bacteria of }
$$

Poisons produced by bacteria

Potatoes for bacterial cultures

Predisposition to bacterial disease

Prevention of bacterial diseases

Protozoa of malaria

Ptomaines

Pure cultures of bacteria

Pus

Putrefaction .

Pyogenic bacteria,

Rooms, living-, pathogenic bacteria in

Scarlet-fever .

$$
\text { " " spread of, by milk }
$$

Sewer gas and diphtheria .

$$
\text { " " " typhoid fever }
$$

Small-pox

Spontaneous generation

Spores, in bacteria

Sputum, dangers from, in tuberculosis

Staphylococcus in wound diseases

Streets, dirty, as source of infection

Streptococcus

$$
\text { " of diphtheria }
$$

Suppuration . 
Surgical diseases, bacteria of

Theatres, bacteria in dust of I I I

Tubercle

" bacillus

Tuberculosis .

" cattle and fowl as sources of infection with

" germ of, in air

" hereditary predisposition to

" infection by, throngh the air

" milk, as a source of infection

" modes of preventing spread of

" sources of infection with

Typhoid bacillus, characters of

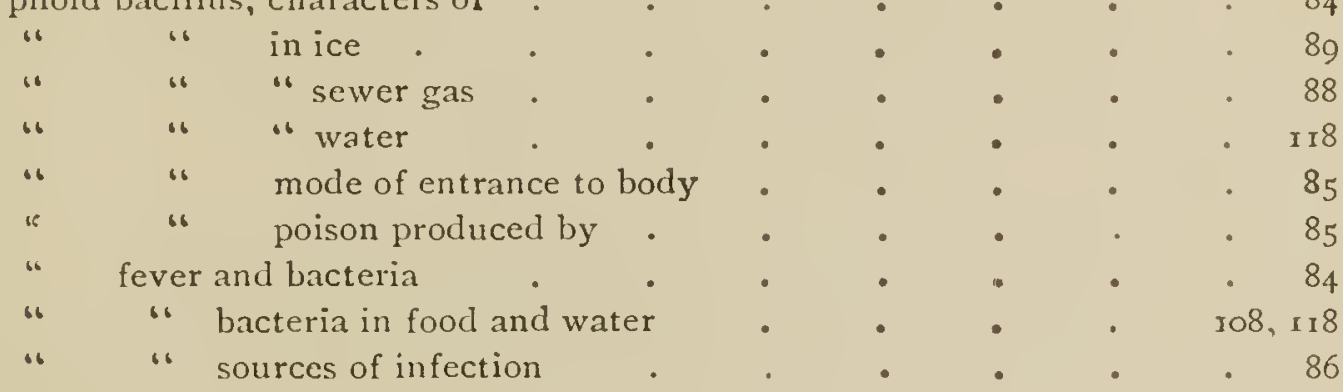

Ventilation and bacteria

" of churches and theatres

" "dwelling-houses

$\begin{array}{ll}\cdot & \text { rog } \\ \cdot & \text { III } \\ \cdot & 113\end{array}$

Water, bacterial analysis of

35,124

bacteria in

" Croton, of New York

" filtration of .

" from wells

" sewage polluted

" spontaneous purification of

" supplies of .

". supply of Albany, N. Y.

“ " " Berlin and London

" " " New York

6

“

"New York

" Philadelphia

typhoid bacillus in

Wells, as sources of water

White blood-cells

Winter cholera

Yellow-fever 



\section{Ii Tert $=5$ sook for \\ Training Tchools for Mnurses.}

By P. M. Wise, M.D., President of the New York State Lunacy Commission; Medical Superintendent St. Lawrence State Hospital; Editor of the State Hospitals Bulletin; Professor of Psychiatry, University of Vermont; Member of the American Medico-Psychological Association, etc. With an introduction by Dr. EDwARD Cowles, Physician-in-Chief and Superintendent McLean Hospital.

Two volumes, $\mathbf{1} 6^{\circ}$, illustrated, sold separately, each

This work will, it is believed, supply a present reed for training schools. It is distinctly a text-book for training schools as distinguished from a text-book for nurses, and its arrangement provides tor all the recitations in a two years' course. The first volume is divided into thirty recitations or chapters, and includes anatomy, physiology, hygiene (and allied subjects-the atmosphere, ventilation, etc.), the sick-room, infection and disinfection, observation of symptoms, clinical recording, etc. Its arrangement is based upon a graded system of teaching; the first volume being adapted for the first year's course. The second volume completes the course and provides for every subject usually taught by recitation in schools for nurses, leaving no requirement for auxiliary books. In fact the two volumes furnish completely all the requirements of the training school for a text-book.

"It is an admirable piece of work. It is written very clearly, and in 1anguage which can be very readily understood by the nurse. It covers the whole ground, and contains a great deal of matter not to be found in other books, and with the adoption of this book other text-books will not be required for the training school."-Dr. G. Alder Blumer, Medical Superintendent of the Utica State Hospital.

"We believe this treatise will be adopted as a text-book in every training school in the country. Its excellency is such as to justify this belief, and surely training schools cannot afford to dispense with the best."-Buffalo Medical Fournal. 


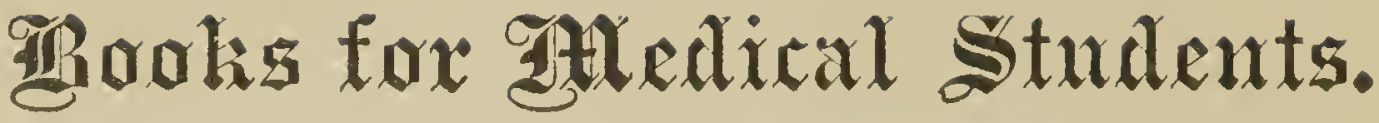

\section{A Text=Book for Training Schools for Nurses.}

By P. M. Wise, M.D., President of the New York State Lunacy Commission ; Medical Superintendent St. Lawrence State Hospital ; Professor of Psychiatry, University of Vermont, etc. With an introduction by Dr. EDward Cowles, Physician-in-Chief and Superintendent McLean Hospital.

Second edition. Two volumes, illustrated, $16^{\circ}$, sold separately, each . . . . . . \$1.25

"This text-book has been adopted by the ten State Hospitals of New York, representing approximately four hundred pupils."

Dr. G. AlDER BLUMER (the medical superintendent of the Utica State Hospital) says: "It is an admirable piece of work. It is written very clearly, and in language which can be very readily understood by the nurse. It covers the whole ground, and contains a great deal of matter not to be found in other books, and with the adoption of this book other text-books will not be required for the training school."

\section{A Text-Book of Materia Medica for Nurses.}

Compiled by Lavinia L. Dock, graduate of Bellevue Training School for Nurses, late superintendent of nurses, Illinois Training School for Nurses, etc.

Third edition, revised and enlarged. Thirteenth thonsand. $12^{\circ} \cdot . \quad . \quad . \quad . \quad . \quad \$ 1.5^{\circ}$

"The work is interesting, valuable, and worthy a position in any library."-N. Y. Medical Record.

"It is written very concisely, and little can be found in it to criticise unfavorably, except the inevitable danger that the student will imagine after reading it that the whole subject has been mastered. The subject of therapentics has been omitted as not a part of a nurse's study, and this omission is highly to be commended. It will prove a valuable book for the purpose for which it is intended."N. Y. Medical Fournal.

\section{An Aid to Materia Medica.}

By Robert H. M. Dawbarn, M.D., Professor of Operative Surgery and Surgical Anatomy, New York Polyclinic.

Third edition, revised and enlarged by Woolsey Hopkins, M.D. I $^{\circ}$. . . . . $\$ 1.25$ 



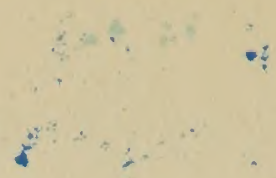

(4)

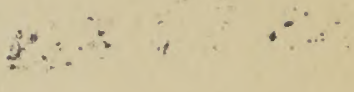

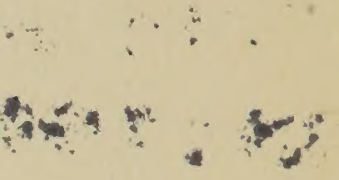

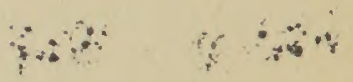

$$
\begin{aligned}
& \because \vdots
\end{aligned}
$$

$\therefore$ -

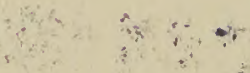

$$
\begin{aligned}
& \text { if } \\
& \therefore \therefore \text { int }
\end{aligned}
$$

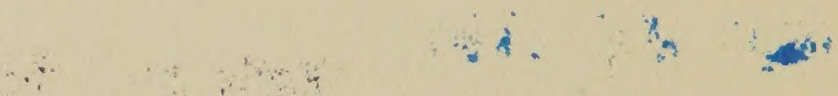




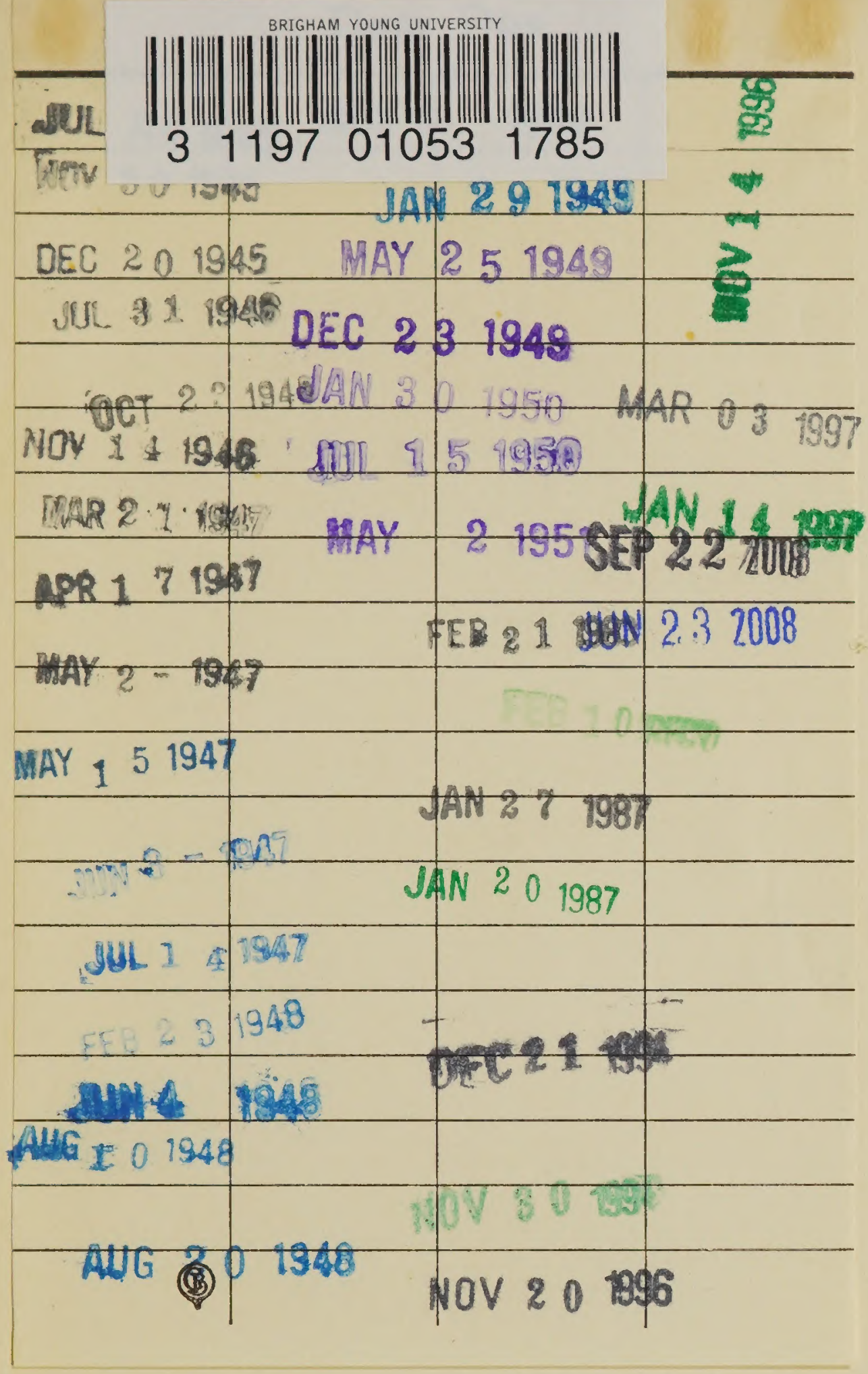


